\title{
POSSIBLE FUNCTIONS OF BIOMINERALIZATION OF SOME TEXTULARIID (FORAMINIFERA) SPECIES OF THE NW IBERIAN MARGIN
}

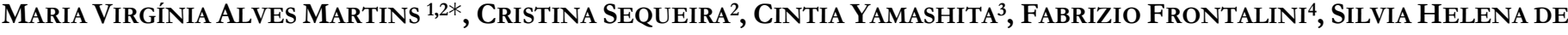

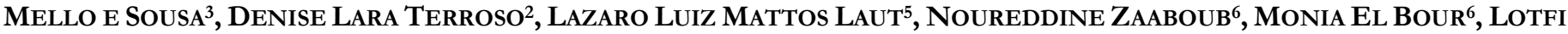 Aleya $^{7}$, Assane Luis Pena ${ }^{8}$ AND FERnANDo Rocha ${ }^{2}$}

1 Laboratório de Micropaleontologia (LMP-UERJ), Universidade do Estado do Rio de Janeiro, Faculdade de Geologia, Departamento de Estratigrafia e Paleontologia. Av. São Francisco Xavier, 524, sala 4037F, Maracanã. 20550-013 Rio de Janeiro, RJ, Brazil. virginia.martins@ua.pt

2 Universidade de Aveiro, GeoBio'Tec, Departamento de Geociências, Campus de Santiago, 3810-193 Aveiro, Portugal. csequeira@ua.pt, laraterroso@ua.pt, tavares.rocha@ua.pt

3 Departamento de Oceanografia Química, Física e Geológica, Instituto Oceanográfico, Universidade de São Paulo, Brazil. cintia.yamashita@usp.br, smsousa@usp.br

4 Università degli Studi di Urbino "Carlo Bo", Dipartimento di Scienze Pure e Applicate (DiSPeA) Urbino, Italy. fabrizio.frontalini@uniurb.it

5 Laboratório de Micropaleontologia (LabMicro), Universidade Federal do Estado do Rio de Janeiro - UNIRIO. Avenida Pasteur 458, Urca, Rio de Janeiro, CEP 22290-240, RJ, Brazil. lazaro.laut@gmail.com

6 Laboratoire du Milieu Marin, Institut National des Sciences et Technologies de la Mer, 2025 Salammbô, Tunisia. nouri_zaaboub@yahoo.fr, monia.elbour@instm.rnrt.tn, elbour_ti@yahoo.fr

7 Université de Bourgogne Franche-Comté, Laboratoire de Chrono-Environnement, UMR CNRS 6249, La Bouloie, F-25030 Besançon Cedex, France.lotfi.aleya@univ-fcomte.fr

8 Universidade Pedagógica - Moçambique, Departamento de Ciências Naturais e Matemática. Rua D. Francisco de Almeida $2^{\circ}$ Bairro, Ponta-Gêa, 2025 - Beira, Mozambique - Caixa-postal: 2025. assanepena@ua.pt

*Corresponding AUthor, virginia.martins@ua.pt

Received on 10 November 2016

Received in revised form on 14 December 2016

Accepted on 18 December 2016

Editor:

Maria Antonieta da Conceição Rodrigues, Universidade do Estado do Rio de Janeiro, Brazil

\section{Abstract}

The main goal of this work is to analyze the elemental composition of the test's wall of some species/specimens of Textulariids (sub-class Subclass Textulariia), collected in surface sediments of the NW Iberian Margin. The elemental analysis was based on the Energy Dispersive Spectroscopy (EDS) on the Scanning Electron Microscope (SEM; Hitachi, S4100) of Textularia deltoidea, Textularia agglutinans, Sabulia conica, Karrerotextularia flintii, Siphotextularia beterostoma, Karreriella bradyi, Spiroplectammina sagittula and Arenoparrella mexicana. The elemental concentrations of the species wall were compared with the mineralogical composition (X-Ray diffraction) of the sediments of the stations where these specimens were
Citation:

Martins, M.V.A., Sequeira, C., Yamashita, C. Frontalini, F., Sousa, S.H.M., Terroso, D.L., Laut, L.L.M., Zaaboub, N., El Bour, M., Aleya, L., Pena, A.L., Rocha, F., 2016. Possible functions of biomineralization of some textulariid (foraminifera) species of the NW Iberian Margin. Journal of Sedimentary Environments, 1(4): 449-452.

collected. The results evidence that whereas the test's wall of $T$. deltoidea, T. agglutinans, $K$. flintii and $S$. heterostoma is characterized by the highest concentrations of $\mathrm{Ca}, \mathrm{Mg}$ and $\mathrm{Y}$ and lowest $\mathrm{Si}$ and $\mathrm{Al}$ contents; S. conica, S. sagittula and $K$. bradyi present intermediate concentrations of the referred variables but display the highest $\mathrm{K}$ content; $A$. mexicana contains the highest $\mathrm{Si}$ and $\mathrm{Al}$ contents and lowest $\mathrm{Ca}, \mathrm{Mg}$ and $\mathrm{Y}$ concentrations. Some species that live in siliciclastic sediments contain high calcium content in their tests (such as T. deltoidea and T. agglutinans), whereas some species much common in the deep-sea display high concentrations of lithogenic elements. Results of this work suggest that some Textulariid species can use the test for "storage" and "excretion" of toxic or useless elements that can be used when necessary. These features seem to be functions of biomineralization of the 


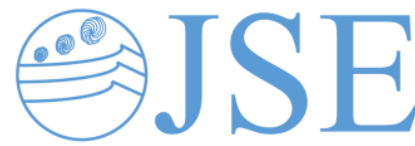

RESEARCH PAPER analyzed species and not only the intention of building a protective envelope.

\section{Introduction}

Benthic foraminifers inhabit a wide range of aquatic environments including open marine, brackish, and freshwater environments (Murray, 2006). Agglutinated foraminifera are benthic organisms with records in sedimentary strata since the Vendian, latest Pre-Cambrian (Gaucher and Sprechmann, 1999) to the Holocene age deposited in most marine and brackish environments (Sen Gupta, 1999). The term "agglutinated" refers to the tests formed by foreign particles that bounded together by organic, calcareous, siliceous, or ferruginous cement (Loeblich and Tappan, 1989). The sedimentary particles may include silt or sand grains, glauconite, sponge spicules, or even other foraminiferal tests (Loeblich and Tappan, 1987). Some species are highly selective in the material used and in its arrangement (Loeblich and Tappan, 1987). Agglutinated tests may be composed of very small particles cemented together and have a very smooth surface, or may be made of larger particles and have a rough surface.

Agglutinated foraminifera can be used in relative age determination but they are particularly valuable as paleoenvironmental indicators (Alve and Murray, 1995; Kaminski and Kuhnt, 1995). The ecology of this group in the deep sea includes for instance: mobile epifaunal forms such as the trochospiral forms and flat disk-shaped forms like Paratrochammina and Discammina; sessile suspension feeders such as the tubular forms like Marsipella and Rhabdammina; opportunistic taxa such as Reophax, Psammosphaera and Textularia in dysaerobic environments; deep infaunal microhabitats in severely dysaerobic environment like Textularia (Kaminski et al., 1995).

The marginal marine habitats, ranging from coastal marshes to inner parts of continental shelves, which are areas of high organic productivity and relatively high environmental variability, are populated by several species of agglutinated benthic foraminifera (Sen Gupta, 1999). For instance, species such as Ammotium salsum, Arenoparrella mexicana, Entria macrescens, Miliammina fusca, Tiphotrocha comprimata and Trochammina inflata are in general found in typical coastal saltmarshes (Murray, 1991).

According to Margulis and Schwartz (1998), foraminifera can be included in a Phylum in which five Classes and one Subclass can be considered: Foraminifera incertae sedis, Globothalamea, Monothalamea and Tubothalamea. The Class Globothalamea includes the Orders: Carterinida, Robertinida and Rotaliida and the Subclass Textulariia.
Keywords: Agglutinated foraminifera. Wall composition. Elemental analysis. SEM. EDS. Biomineralization.

Kaminski (2004) considered four orders in the Subclass Textulariia (here named Textulariids) based mainly on the morphology, wall structure, and cement composition. According to this author, the cement used to agglutinate the particles to form the test's wall may be organic (as in the Astrorhizida), calcareous and canaliculate (as in the Textulariida), or of mixed nature (as in the Lituolida and Loftusiida, which contains both organically-cemented, calcareous, and microgranular types). The organic cement occupying the intergranular space within the wall may be present in the form of strands, meshwork, or foam (Bender and Hemleben, 1988).

\subsection{Aim of the research}

The main goal of this work is to document the elemental composition of the test's wall of selected species of Textulariids collected in surface sediments of a siliciclastic continental margin, NW Iberian Margin. Textulariids species are quite common in the Iberian Continental Margin (Levy et al., 1993, 1995; Mendes et al., 2004; Martins et al., 2012a, 2015a). Their preferred microhabitat is commonly $0-0.5 \mathrm{~cm}$, or the first or the first two centimeters below the surface of the sediment where the abundance of living organisms is maximal (Corliss, 1991). Sediment granulometry can greatly influence the distribution of species of textulariids (Arnold, 1983).

\section{Material and methods}

On the basis of Energy Dispersive Spectroscopy (EDS) on the Scanning Electron Microscope (SEM; Hitachi, S4100), this work analyses the elemental composition of selected specimens belonging to the Subclass Textulariia Mikhalevich, 1980 (according to Hayward, 2013):

Textularia deltoidea Reuss, 1850, Textularia agglutinans d'Orbigny, 1839, Sabulia conica (d'Orbigny, 1839), Karrerotextularia flintii (Cushman, 1911), Siphotextularia beterostoma (Fornasini, 1896), Karreriella bradyi (Cushman, 1911), Spiroplectammina sagittula (Defrance, 1824) and Arenoparrella mexicana (Kornfeld, 1931). The species taxonomy was based on Hayward (2013) also considering specific references cited along the text.

The analyzed specimens were collected in surface sediments long the NW Iberian Continental Margin 
between 0 and $2765 \mathrm{~m}$ water depth (coordinates in Appendix 1; Fig. 1).

The sedimentary mineralogy was also used in this work. The sedimentological data of the Aveiro continental shelf and slope (Stations 1-5, 8-10) were obtained by Martins et al. (2012a).

The sediments' mineralogy was determined by X-Ray diffraction techniques according to the procedures described by Martins et al. (2007).

The pore water sedimentary $\mathrm{pH}$, and TOC values of Station 7 at the Ria de Aveiro, were based on Martins et al. (2015b).

The EDS on SEM analysis were performed in the Department of Materials Engineering (Universidade de
Aveiro, Portugal). Four specimens of $T$. deltoidea collected in different localities were analyzed. The chemical composition of different parts of the test was also evaluated in one of the four analyzed specimens of T. deltoidea (Appendix 1).

Pearson correlations and R-mode cluster analyses (CA) using "Weighted pair group average method" and "1 Pearson r" based on the elemental composition of the analyzed specimens were performed.

The variables were logarithmically transformed [log $(\mathrm{X}+1)$ ] before the analyses. The CA was carried out in Statistica 12.0 software.
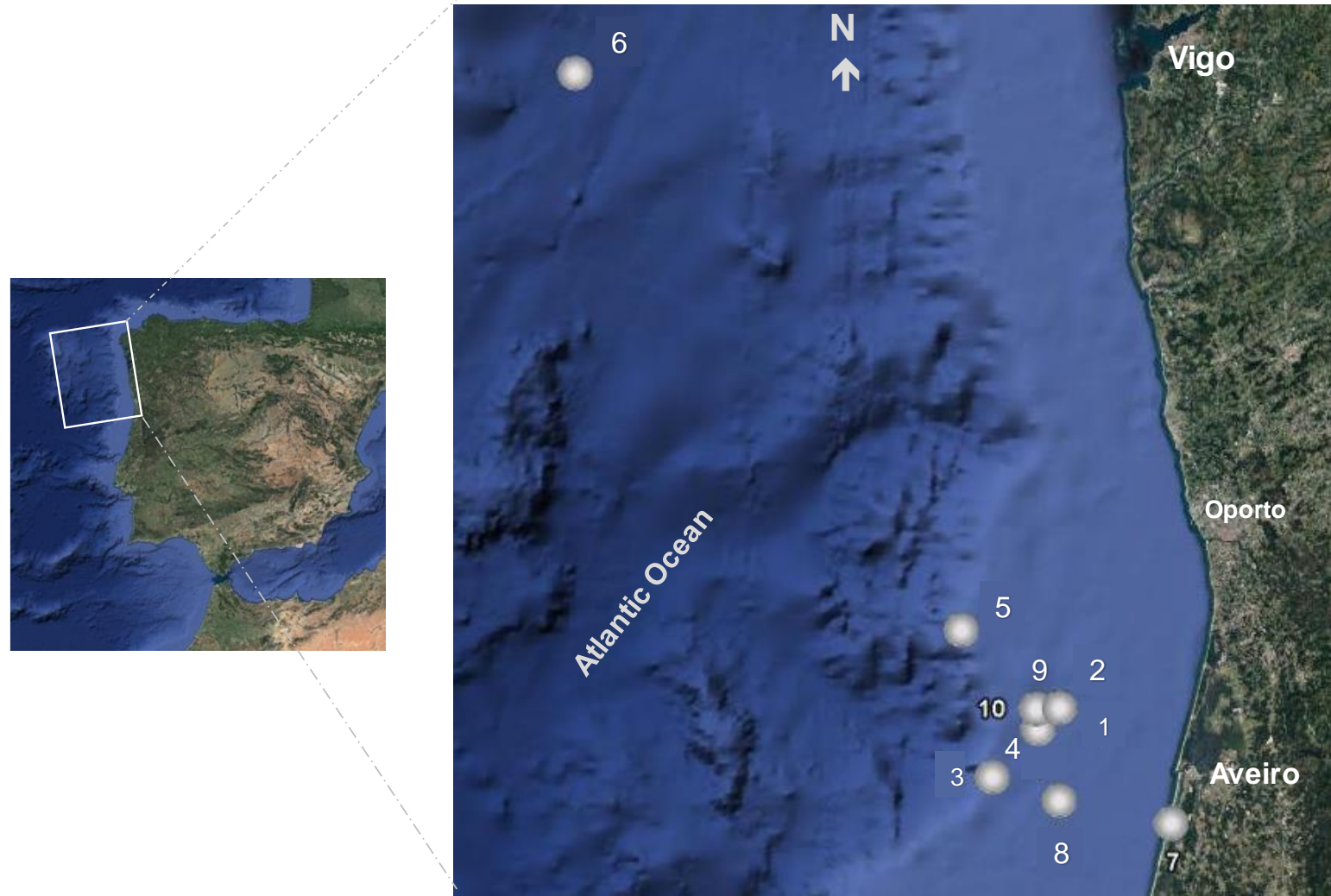

Fig. 1. Samples location from where the analyzed specimens were collected in surface sediments along the NW Iberian Continental Margin between 0 and $2765 \mathrm{~m}$ water depth. Adapted from Google Earth.

\section{Results}

\subsection{Notes about the species taxonomy and morphology and results of EDS on SEM analyses}

Phylum Foraminifera (d'Orbigny, 1826)

Class Globothalamea Pawlowski, Holzmann and Tyszka, 2013

Subclass Textulariia Mikhalevich, 1980

Order Textulariida (Delage and Hérouard, 1896)
Suborder Textulariina Delage and Hérouard, 1896

Superfamily Textularioidea Ehrenberg, 1838

Family Textulariidae Ehrenberg, 1838

Subfamily Textulariinae Ehrenberg, 1838

Genus Textularia Defrance, 1824

\section{Textularia deltoidea Reuss, 1850}

(Figs. 2, 3)

1850 Textularia deltoidea Reuss; p. 381, pl. 49, fig. 4.

1995 Textularia deltoidea Reuss; Levy et al., p. 20, pl. 3, fig. 6. 
Morphological description

The biserial test with a delta shape has the lateral margin compressed and a greater thickness in its central zone. Its initial extremity is acute and triangular whereas more dilated in the oral portion. Chambers separated by horizontal sutures are generally sub-arched. The last two chambers, more inflated, show a less compressed outline. The aperture is a slit at the base of the oral face.

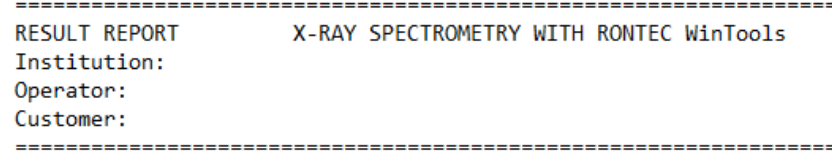

\begin{tabular}{|c|c|}
\hline 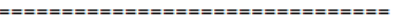 & 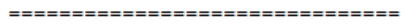 \\
\hline RONTEC EDWIN WinTools & GERAL5 $\quad 29.07 .2016(15: 55)$ \\
\hline version: 3.1 eng & Eo: $25.0 \mathrm{keV}$ (T0:35.0 TI: -4.0$)$ \\
\hline
\end{tabular}

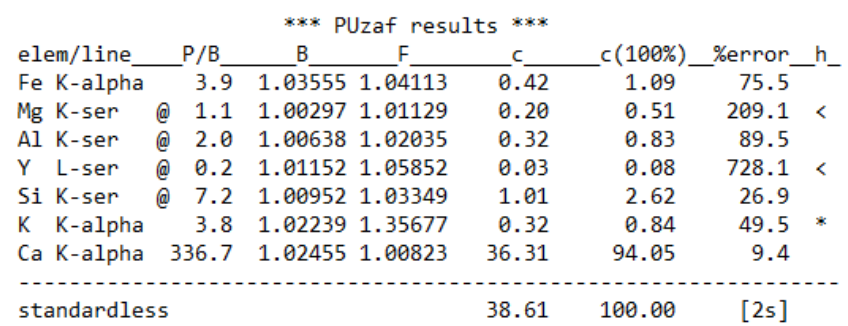
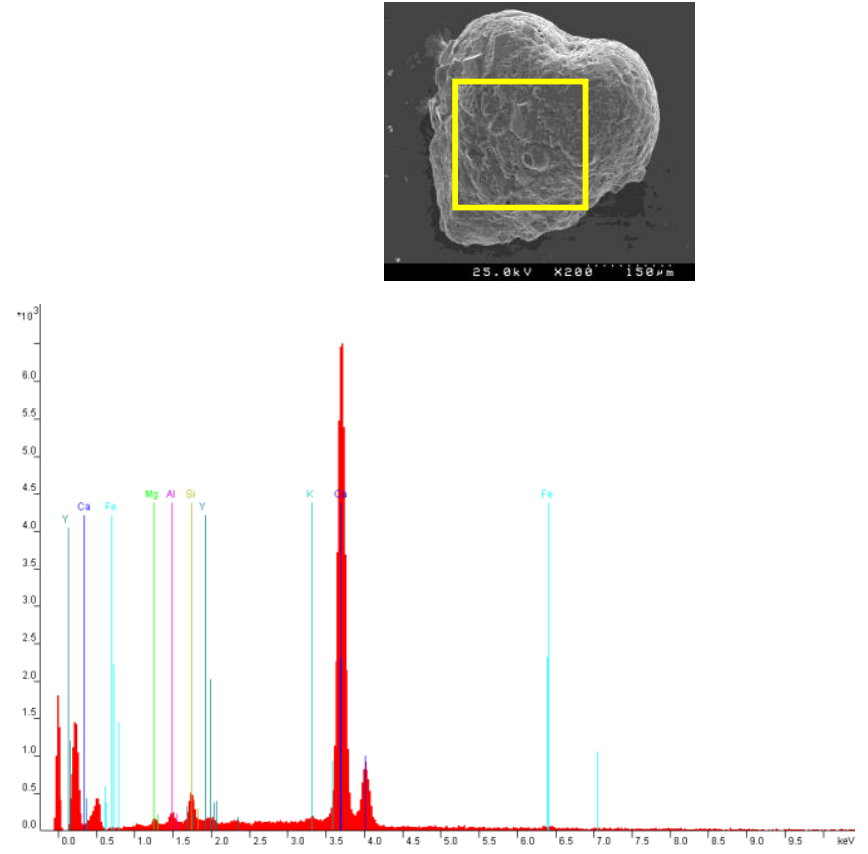

Specimen 1

RESULT REPORT X-RAY SPECTROMETRY WITH RONTEC WinTools
Institution:

Institution:

Operator:

Customer:

\begin{tabular}{|c|c|c|c|c|c|c|}
\hline \multirow{2}{*}{\multicolumn{3}{|c|}{ 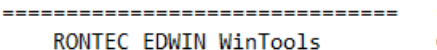 }} & \multicolumn{4}{|c|}{ 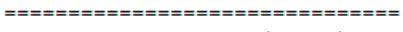 } \\
\hline & & & \multicolumn{4}{|c|}{ 29.07.2016 (15:27) } \\
\hline \multicolumn{3}{|c|}{ 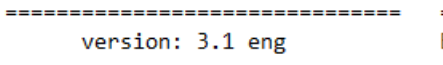 } & \multicolumn{4}{|c|}{$\begin{array}{l}============================= \\
\text { EO }: 25.0 \mathrm{keV} \quad(\text { TO }: 35.0 \text { TI }:-4.0)\end{array}$} \\
\hline \multicolumn{7}{|c|}{ *** PUzaf results *** } \\
\hline Fe K-alpha & 13.8 & 1.034921 .04226 & 1.43 & 2.87 & 37.5 & \\
\hline Mg K-ser & @ 17.0 & 1.002921 .00971 & 3.01 & 6.03 & 24.9 & \\
\hline Al K-ser & (@) 5.9 & 1.006271 .01695 & 0.94 & 1.89 & 39.0 & \\
\hline Y L-ser & @ 1.6 & 1.011321 .04490 & 0.32 & 0.64 & 184.4 & $<$ \\
\hline Si K-ser & @ 20.5 & 1.009361 .02550 & 2.81 & 5.63 & 18.5 & \\
\hline K K-alpha & 10.7 & 1.022001 .25794 & 0.95 & 1.91 & 26.9 & $*$ \\
\hline Ca K-alpha & 385.0 & 1.024121 .00951 & 40.37 & 81.02 & 10.1 & \\
\hline standardles & & & 49.83 & 100.00 & {$[2 s]$} & \\
\hline
\end{tabular}
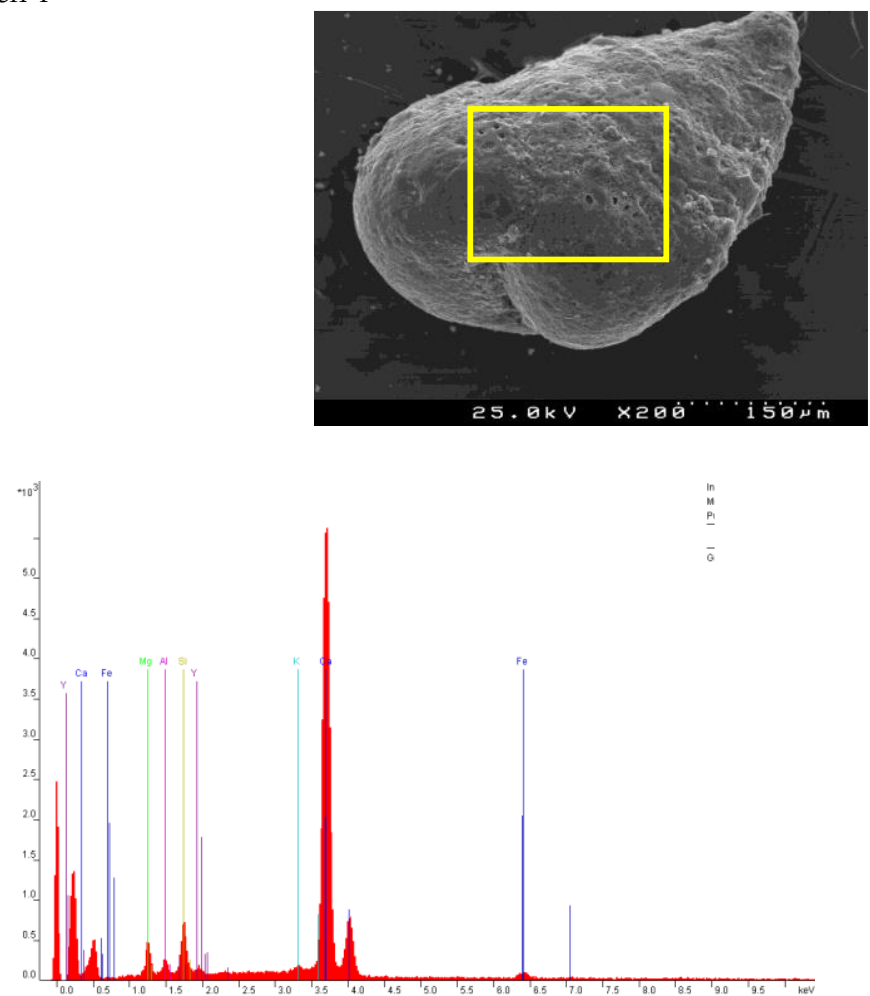

Specimen 2

Fig. 2. Results of the EDS Analysis on the SEM of the general elemental composition of the test of Textularia deltoidea. 


\begin{tabular}{|c|c|}
\hline $\begin{array}{l}\text { RESULT REPORT } \\
\text { Institution: } \\
\text { Operator: } \\
\text { Customer: }\end{array}$ & X-RAY SPECTROMETRY WITH RONTEC WinTools \\
\hline
\end{tabular}

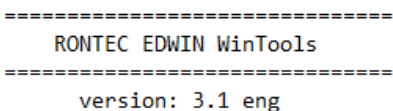

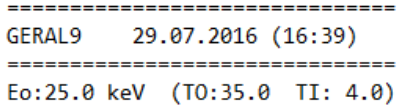

\begin{tabular}{|c|c|c|c|c|c|c|c|}
\hline elem/line_ & $P / B$ & $\begin{array}{c}* * * \\
B \\
B\end{array}$ & $\begin{array}{c}\text { Jzaf res } \\
\text { F }\end{array}$ & $\begin{array}{cc}5 \\
\mathrm{C}\end{array}$ & $c(100 \%)$ & \%error & h_ \\
\hline Fe K-alpha & $7 . \overline{9}$ & $1.03 \overline{507}$ & $1.04 \overline{251}$ & $0 . \overline{83}$ & 1.79 & 43.8 & \\
\hline Mg K-ser & 5.1 & 1.00293 & 1.01064 & 0.91 & 1.98 & 42.4 & \\
\hline Al K-ser & 4.2 & 1.00629 & 1.01879 & 0.68 & 1.47 & 40.1 & \\
\hline Y L-ser & @ 1.7 & 1.01136 & 1.04570 & 0.36 & 0.78 & 169.4 & $<$ \\
\hline Si K-ser & (@) 28.8 & 1.00940 & 1.02622 & 3.97 & 8.61 & 14.2 & \\
\hline S K-ser & (@) 2.7 & 1.01496 & 1.07017 & 0.30 & 0.65 & 100.7 & $<$ \\
\hline K K-alpha & 6.6 & 1.02209 & 1.26503 & 0.59 & 1.27 & 32.3 & * \\
\hline Ca K-alpha & 364.3 & 1.02422 & 1.00892 & 38.50 & 83.45 & 9.7 & \\
\hline tandardle & & & & 46.14 & 100.00 & {$[2 s]$} & \\
\hline
\end{tabular}

Specimen 3

\begin{tabular}{|c|c|}
\hline $\begin{array}{l}\text { RESULT REPORT } \\
\text { Institution: } \\
\text { Operator: } \\
\text { Customer: }\end{array}$ & X-RAY SPECTROMETRY WITH RONTEC WinTools \\
\hline
\end{tabular}

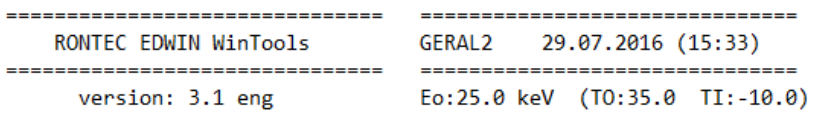

\begin{tabular}{|c|c|c|c|c|c|c|}
\hline elem/line & $\mathrm{P} / \mathrm{B}$ & *** PUzaf res & $\begin{array}{c}s * * * \\
c\end{array}$ & $c(100 \%)$ & \%error & $h_{-}$ \\
\hline Fe K-alpha & 3.3 & $1.034 \overline{4811.04212}$ & $0 . \overline{34}$ & 2.52 & 137.5 & $<$ \\
\hline Mg K-ser & 2.0 & 1.002911 .01110 & 0.36 & 2.66 & 89.2 & \\
\hline Al K-ser & 2.2 & 1.006251 .01917 & 0.35 & 2.59 & 82.9 & \\
\hline Si K-ser & 8.7 & 1.009331 .02710 & 1.18 & 8.73 & 35.9 & \\
\hline K K-alpha & -4.2 & 1.021931 .29252 & 0.00 & 0.01 & 3.1 & * \\
\hline Ca K-alpha & 108.1 & 1.024041 .00928 & 11.32 & 83.50 & 14.3 & \\
\hline standardles & & & 13.56 & 100.00 & {$[2 s]$} & \\
\hline
\end{tabular}
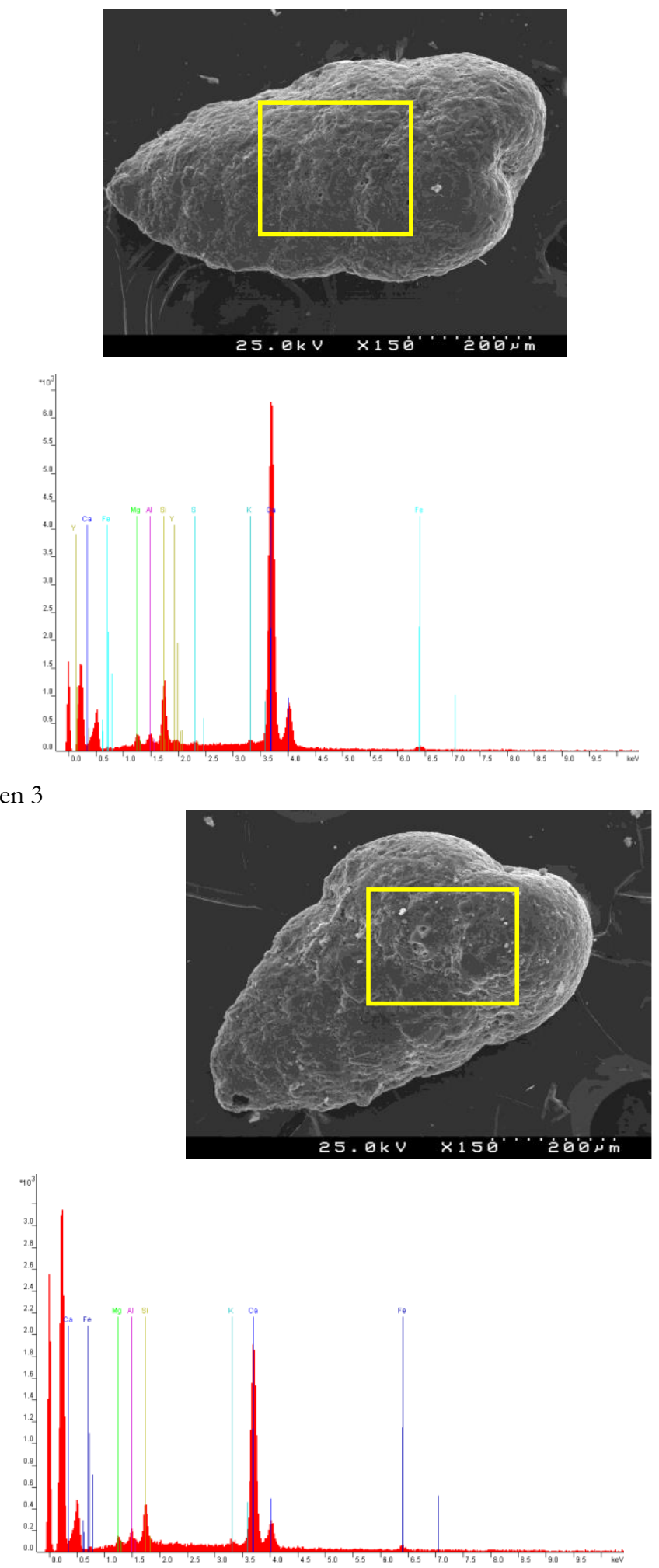

Specimen 4

Fig. 2. (cont) Results of the EDS Analysis on the SEM of the general elemental composition of the test of Textularia deltoidea 

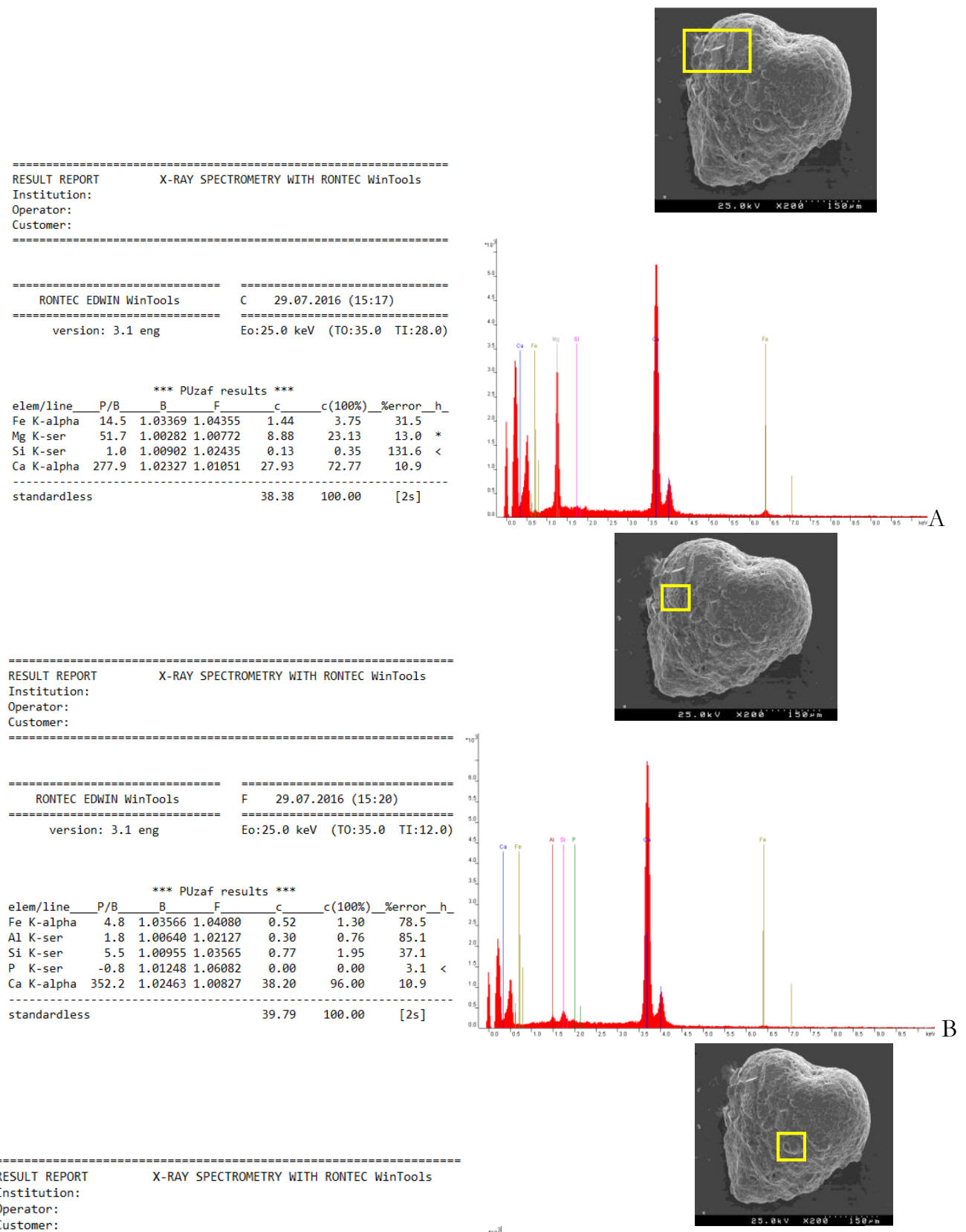

\begin{tabular}{|c|c|}
\hline $\begin{array}{l}\text { RESULT REPORT } \\
\text { Institution: } \\
\text { Operator: } \\
\text { Customer: }\end{array}$ & X-RAY SPECTROMETRY WITH RONTEC WinTools \\
\hline
\end{tabular}

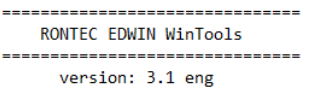
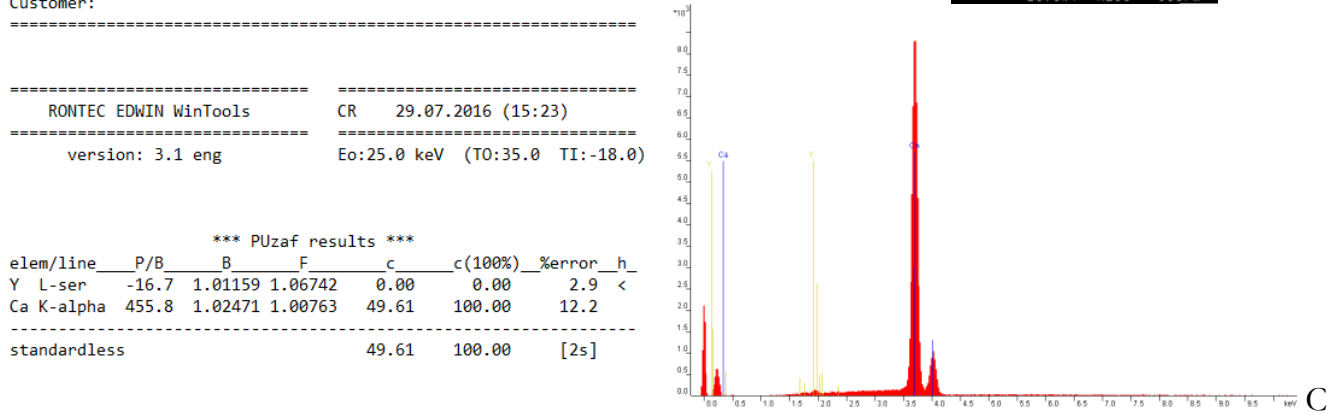

Fig. 3. Results of the EDS Analysis on the SEM of different particles included in the test of specimen 1 of $T$. deltoidea. A - cubes; B - a carbonated perforated particle (perhaps a bioclast); C - A pore surrounded by an elevation of the text similar to a volcano-like shape. 
EDS Analysis on the SEM

The results of the analysis of the elemental composition of four different specimens of $T$. deltoidea are presented in Figure 2 and Appendix 1. Maximum, minimum and mean values were included in Table 1 . The results for the overall composition of the test's wall of these species indicate that the most abundant elements are $\mathrm{Ca}(80-95 \%)$ and $\mathrm{Si}(<10 \%)$. The test's wall also includes other elements such as $\mathrm{Mg}$ (mean 3\%), Fe (mean 2\%), $\mathrm{Al}($ mean $2 \%$ ), $\mathrm{K}$ (mean 1\%) and sometimes $\mathrm{Y}(<1 \%)$ and $\mathrm{S}(<1 \%)$.

The results presented in Figure 3 evidence considerable differences in elemental concentrations in selected particles of the wall of the specimen 1 of $T$. deltoidea. In Figure $3 \mathrm{~A}$, the elemental composition of a particle with a cube shape is composed essentially by $\mathrm{Ca}(72.77 \%), \mathrm{Mg}(23.13 \%)$ and reduced concentrations of $\mathrm{Fe}(3.75 \%)$ and $\mathrm{Si}(0.35 \%)$. In Figure 3B a carbonated perforated particle (bioclast perhaps from a carbonated foraminifera) is essentially composed of $\mathrm{Ca}(96.00 \%)$ with minor contributions of $\mathrm{Si}(1.95 \%)$ and $\mathrm{Fe}$ $(1.30 \%)$. In Figure 3C, a pore surrounded by an elevation of the test with a volcano shape is composed only by $\mathrm{Ca}$ $(100 \%)$. In this specimen, several similar structures to that one were observed.

Tab. 1. Maximum, minimum and mean values of the elemental composition of four different specimens of T. deltoidea.

\begin{tabular}{l|ccc} 
Elements & Max & Min & Mean \\
\hline $\mathrm{Ca}(\%)$ & 94.05 & 81.02 & 85.50 \\
$\mathrm{Si}(\%)$ & 8.73 & 2.62 & 6.40 \\
$\mathrm{Fe}(\%)$ & 2.87 & 1.09 & 2.10 \\
$\mathrm{Al}(\%)$ & 2.59 & 0.83 & 1.70 \\
$\mathrm{Mg}(\%)$ & 6.03 & 0.51 & 2.80 \\
$\mathrm{~K}(\%)$ & 1.91 & 0.01 & 1.00 \\
$\mathrm{Y}(\%)$ & 0.78 & 0.08 & 0.50
\end{tabular}

Textularia agglutinans d'Orbigny, 1839

(Fig. 4A)

1839 Textularia agglutinans d'Orbigny, p. 144, pl. 1, Figs. 17-18, 32-34. 1899 Textularia agglutinans d' Orbigny, Flint, p.284, pl. 29, Fig. 1. 2015 Textularia agglutinans d'Orbigny, Merkado et al., pp. 1-21.

Morphological description

Test biserial, elongated, conical, pointed in the initial portion and laterally convex. The wall is agglutinated, rough, and whitish. The chambers become more inflated as they are added, sutures are sometimes not clearly visible due to the irregular agglutinated materials. The aperture has a low archshape.

EDS Analysis on the SEM

The general composition of T. agglutinans (Fig. 4A, Appendix $1)$, evidences that the wall of the analyzed specimens is mainly composed of $\mathrm{Ca}(85 \%)$, also including a small proportion of $\mathrm{Si}(\approx 5 \%), \mathrm{K}(\approx 5 \%), \mathrm{Al}(\approx 3 \%), \mathrm{K}(\approx 2 \%)$ and $\operatorname{Mg}(\approx 1 \%)$.

Genus Sabulia Loeblich and Tappan, 1985

\section{Sahulia conica (d'Orbigny, 1839)}

(Fig. 4B)

1839 Textularia conica d'Orbigny, p. 143, pl. 1, Figs. 19-20. 1986 Textularia conica d'Orbigny; Mathieu, p. 230, pl. 2, Fig. 3. 1995 Textularia conica d'Orbigny; Levy et al., p. 20, pl. 3, Fig. 5. 1995 Textularia conica d'Orbigny; Yassini and Jones, p. 75, Figs. 101, 109. 1998 Textularia conica d'Orbigny; Robertson, p. 30, pl. 5, Fig. 3.

2012 Textularia conica d'Orbigny; Debenay, p. 96.

Morphological description:

Test biserial, conical, commonly wider than high, slightly compressed. In cross-section, there is an oval shape and a triangular longitudinal contour with the apex bluntly pointed. The width of the oral face is greater than the length of the test. The thickest zone is in the middle region, rapidly tapering towards the periphery. Its wide and low chambers are not clear; the sutures slightly arched, nearly horizontal, are in general undistinguishable. The wall is agglutinated and shiny consisting of grains of several sizes. The aperture, a nearly straight slit, with a distinct flaplike lip bordering the opening, is located at the inner base of the apertural face, of the last chamber.

EDS Analysis on the SEM

The general composition of the test's wall of S. conica (Fig. 4B) includes mostly Si $(34.91 \%), \mathrm{Ca}(26.76 \%), \mathrm{K}(23.03 \%)$ and a small proportion of $\mathrm{Al}(7.84 \%), \mathrm{Mg}(4.04 \%), \mathrm{S}(2.03 \%)$ and $(\mathrm{Fe} \mathrm{1,37 \% ).}$

Subfamily Siphotextulariinae Loeblich and Tappan, 1985

Genus Karrerotextularia Le Calvez, de Klasz and Brun, 1974

\section{Karrerotextularia flintii (Cushman, 1911)}

(Fig. 5A)

1911 Textularia flintii Cushman, p. 21, text-fig. 36

1988 Siphotextularia flintii (Cushman); Zheng, p. 125; pl. 35; figs 1-2. 1995 Siphotextularia flintii (Cushman); Levy et al., p. 21-22, pl.3, fig. 2. 2012 Siphotextularia flintii (Cushman); Debenay, p. 93. 


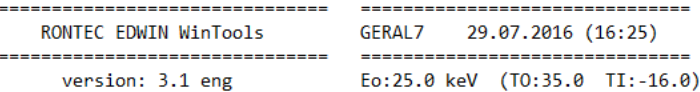

\begin{tabular}{|c|c|c|c|c|c|c|c|}
\hline \multicolumn{8}{|c|}{$* * *$ PUzaf results $* * *$} \\
\hline Fe K-alpha & $21 . \overline{7}$ & 1.03540 & 1.04053 & 2.29 & 4.57 & 23.8 & \\
\hline Mg K-ser & @ 2.6 & 1.00296 & 1.01049 & 0.46 & 0.92 & 119.3 & \\
\hline Al K-ser & 9.0 & 1.00635 & 1.01792 & 1.45 & 2.88 & 29.8 & \\
\hline Y L-ser & 0.0 & 1.01147 & 1.04976 & 0.00 & 0.00 & 999.0 & $<$ \\
\hline Si K-ser & @ 17.0 & 1.00948 & 1.02785 & 2.36 & 4.70 & 16.7 & \\
\hline K K-alpha & 9.1 & 1.02230 & 1.29066 & 0.80 & 1.60 & 22.3 & \\
\hline Ca K-alpha & 402.3 & 1.02445 & 1.01004 & 42.86 & 85.34 & 8.5 & \\
\hline tandard & & & & 50.22 & 100.00 & {$[2 s]$} & \\
\hline
\end{tabular}

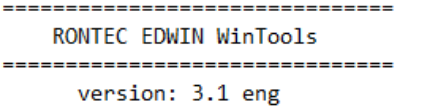

$$
\begin{aligned}
& \text { GERAL3 } 29.07 .2016 \quad(15: 40) \\
& ========================= \\
& \text { EO: } 25.0 \mathrm{keV} \quad(\text { TO }: 35.0 \text { TI }:-18.0)
\end{aligned}
$$

\begin{tabular}{|c|c|c|c|c|c|c|}
\hline elem/line_ & $\mathrm{P} / \mathrm{B}$ & *** PUzaf res & s $* * *$ & $c(100 \%)$ & \%error & h_ \\
\hline Fe K-alpha & 6.2 & 1.031671 .05237 & $0 . \overline{56}$ & 1.37 & 71.2 & \\
\hline Mg K-ser & 10.6 & 1.002651 .01481 & 1.66 & 4.04 & 42.2 & * \\
\hline Al K-ser & 22.9 & 1.005681 .02222 & 3.22 & 7.84 & 31.7 & * \\
\hline Si K-ser & 116.6 & 1.008481 .01124 & 14.35 & 34.91 & 23.4 & * \\
\hline S K-ser & 8.3 & 1.013511 .02863 & 0.84 & 2.03 & 50.0 & * \\
\hline K K-alpha & 99.9 & 1.019951 .04431 & 9.47 & 23.03 & 15.9 & \\
\hline Ca K-alpha & 118.9 & 1.021871 .01094 & 11.00 & 26.76 & 13.7 & \\
\hline standardles & & & 41.11 & 100.00 & {$[2 s]$} & \\
\hline
\end{tabular}
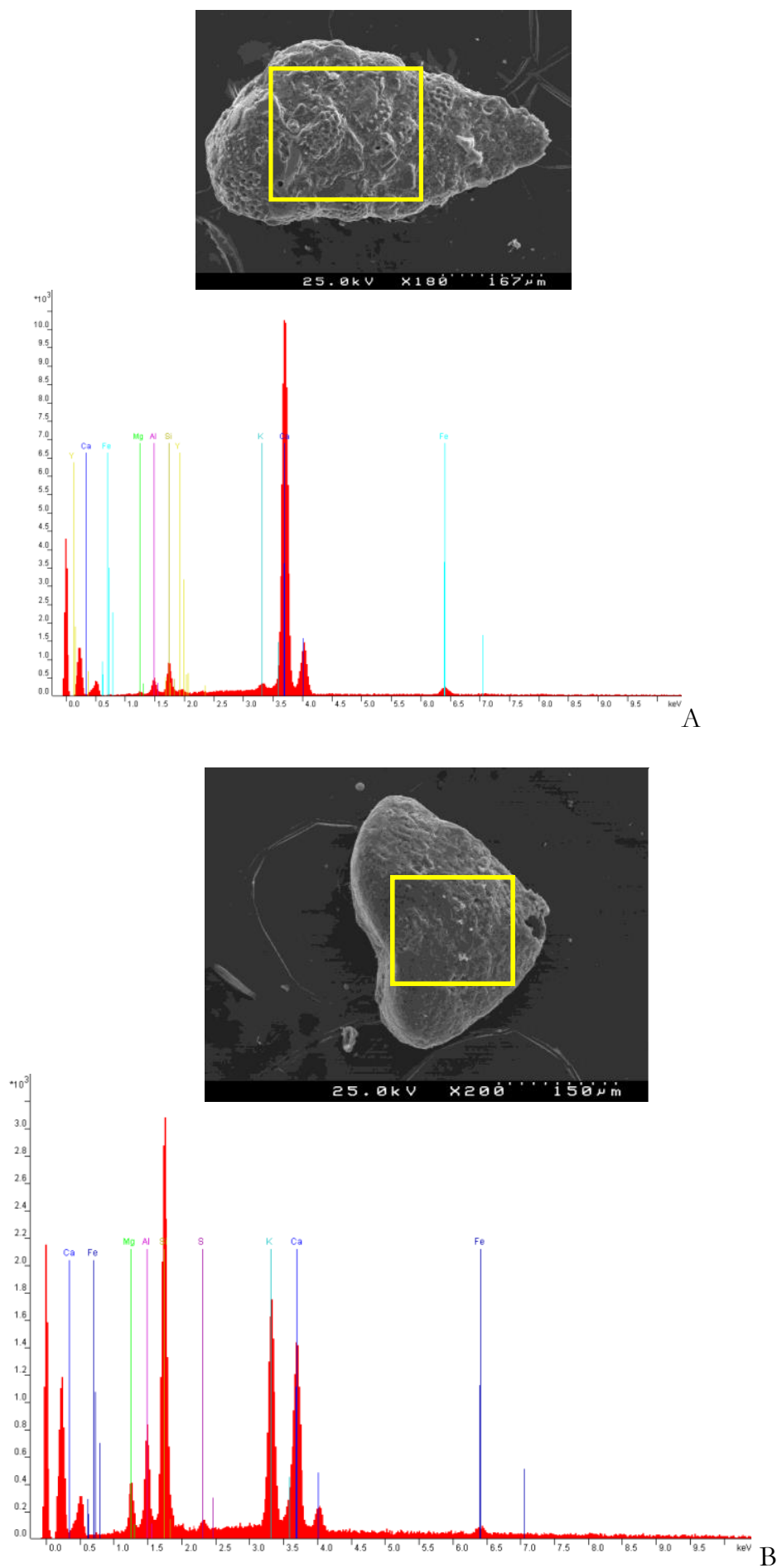

Fig. 4. Results of the EDS Analysis on the SEM of the general composition of the test of: A. Textularia agglutinans; B. Sabulia conica. 
Morphological description:

Test biserial, triangular in front view, irregularly rhombic in end view, rapidly increasing in size from the early portion, rather thick, but somewhat laterally compressed, chambers numerous, low and broad, inflated, separated by curved sutures; wall composed by fine and coarser grained particles. The aperture is a wide elongated slit slightly above the inner base of the chamber, with a slightly raised lip. Length about $1 \mathrm{~mm}$.

EDS Analysis on the SEM

The general composition of the test's wall of $K$. flintii (Fig. $5 \mathrm{~A})$ is essentially composed of $\mathrm{Ca}(81.05 \%)$ and $\mathrm{Si}(8.8 \%)$ and small proportion of Fe $(2.29 \%), \mathrm{K}(2.19 \%), \mathrm{Y}(2.13 \%)$, $\mathrm{Al}(2.06 \%), \mathrm{Na}(0.97 \%)$ and $\mathrm{Mg}(0.42 \%)$.

Genus Siphotextularia Finlay, 1939

\section{Siphotextularia heterostoma (Fornasini, 1896)}

\section{(Fig. 5B)}

1896 Textularia heterostoma Fornasini, p. 2, figs. 7-9.

1988 Siphotextularia heterostoma (Fornasini); Zheng, p. 126; pl. 38, fig. 4. 1994 Siphotextularia heterostoma (Fornasini); Loeblich and Tappan, p. 31; pl. 40, figs 17-18.

2012 Siphotextularia heterostoma (Fornasini); Debenay, p. 94.

Morphological description:

Test biserial, elongated, laterally compressed, triangular in lateral view, with rounded edges; chambers increasing progressively as they are added; sutures distinct, oblique; the wall has perforations and includes fine grained material and coarser one; the aperture areal is an elliptical slit at the end of an everted neck in the last chamber.

EDS Analysis on the SEM

The general composition of the test's wall of $S$. heterostoma (Fig. 5B) contains mostly $\mathrm{Ca}(92.77 \%)$ and small proportion of Si $(2.63 \%), \mathrm{Na}(1.68 \%), \mathrm{Al}(1.16 \%), \mathrm{K}(1.06 \%), \mathrm{Y}(0.48 \%)$ and $\mathrm{Mg}(0.22 \%)$.

Superfamily Eggerelloidea Cushman, 1937

Family Eggerellidae Cushman, 1937

Subfamily Eggerellinae Cushman, 1937

Genus Karreriella Cushman, 1933

\section{Karreriella bradyi (Cushman, 1911)}

(Fig. 6A)

1911 Gaudryina bradyi Cushman; p. 67, pl. 67, Fig. 107 a-c

1937 Karreriella bradyi (Cushman); Cushman, p. 135; pl. 16, figs 6-11.

1988 Karreriella bradyi (Cushman); Zheng, p. 94; pl. 45, fig. 10; pl. 46, fig. 1. 1994 Karreriella bradyi (Cushman); Loeblich and Tappan, p. 25; pl. 30, figs 8-16.

1990 Karreriella bradyi (Cushman); Sprovieri and Hasegawa, p. 455, pl. 1, Figs. 9-10.
1994 Karreriella bradyi (Cushman); Jones, p. 50, pl. 46, Figs. 1-4. 1998 Karreriella bradyi (Cushman); Robertson, p. 26, pl. 4, Fig. 1.

Morphological description:

The stout test initially presents a trochospiral winding, becoming triserial and later biserial. The biserial portion comprises the major part of the test total length. The test with an elongated longitudinal axis has a cylindrical, oval or subcircular cross-contour. The relatively large inflated chambers gradually increase in size as they are added. The sutures are depressed and sharp. The finely agglutinated wall has a smooth appearance and is perforated, displaying small pores. The aperture areal, composed by a slit situated at the base of the last chamber, is surrounded by a distinct lip.

EDS Analysis on the SEM

The general composition of the test's wall of $K$. bradyi (Fig. 6A) encompasses mainly $\mathrm{Ca}(63.96 \%) \mathrm{Si}(22.60 \%)$ and $\mathrm{Al}$ $(4.51 \%)$ and small proportion of $\mathrm{K}(3.11 \%), \mathrm{Na}(2.28 \%), \mathrm{Mg}$ $(1.78 \%), \mathrm{S}(1.18 \%)$ and $\mathrm{Fe}(0.58 \%)$.

Order Lituolida Lankester, 1885

Suborder Spiroplectamminina Mikhalevich, 1992

Superfamily Spiroplectamminoidea Cushman, 1927

Family Spiroplectamminidae Cushman, 1927

Subfamily Spiroplectammininae Cushman, 1927

Genus Spiroplectammina Cushman, 1927

\section{Spiroplectammina sagittula (Defrance, 1824)}

(Fig. 6B)

1824 Textularia sagittula Defrance; p. 177, fig. 2.

1987 Textularia sagittula Defrance; Jörissen, p. 46, pl. 3, fig. 12.

1994 Spiroplectinella wrightii (Silvestri); Jones, p. 47, pl. 42, figs. 17-18.

1995 Textularia sagittula Defrance; Yassini and Jones, p. 76, figs. 105-108.

Morphological description:

The test is elongate, with an early planispiral coil of few chambers followed by biserially arranged chambers; the chambers are distributed in opposite pairs, gradually increasing in size. The chambers are numerous, longer than high, presenting defined sutures, slightly depressed and horizontally arranged. The test is compressed, with subangular borders and the maximum thickness located in the median region. The aperture in the form of a small interiomarginal arch, without lip, extends along the sutural line separating the last two chambers. The agglutinated wall integrates grains of different sizes and very fine material.

EDS Analysis on the SEM

The general composition of the test's wall of S. sagittula (Fig. 6B) comprises mostly $\mathrm{Ca}(63.96 \%) \mathrm{Si}(22.60 \%)$ and $\mathrm{Al}$ $(4.51 \%)$ and small proportion of $\mathrm{K}(3.11 \%), \mathrm{Na}(2.28 \%), \mathrm{Mg}$ $(1.78 \%), \mathrm{S}(1.18 \%)$ and $\mathrm{Fe}(0.58 \%)$. 


\begin{tabular}{|c|c|}
\hline $\begin{array}{l}\text { RESULT REPORT } \\
\text { Institution: } \\
\text { Operator: } \\
\text { Customer: }\end{array}$ & X-RAY SPECTROMETRY WITH RONTEC WInTools \\
\hline
\end{tabular}

\begin{tabular}{|c|c|}
\hline 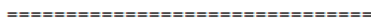 & 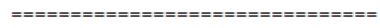 \\
\hline RONTEC EDWIN WinTools & 29.07.2016 (16:49) \\
\hline version: 3.1 & Eo: $25.0 \mathrm{keV}$ \\
\hline
\end{tabular}

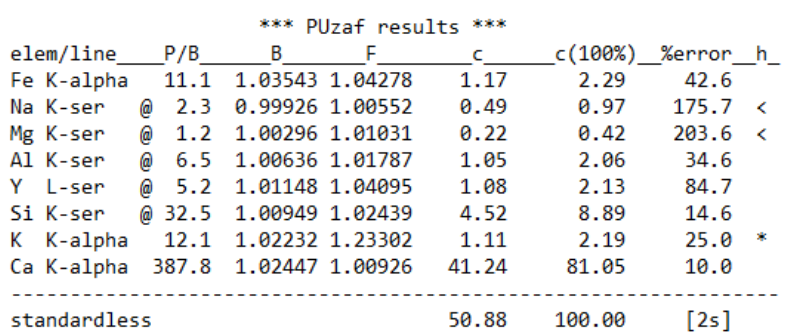

\begin{tabular}{|c|c|c|c|c|c|}
\hline \multirow{2}{*}{\multicolumn{3}{|c|}{ 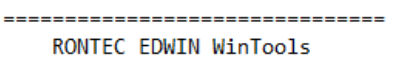 }} & \multicolumn{3}{|c|}{ 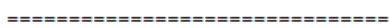 } \\
\hline & & & \multicolumn{3}{|c|}{ G11 29.07.2016 (17:28) } \\
\hline \multicolumn{3}{|c|}{ 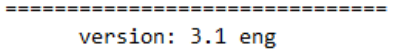 } & \multicolumn{3}{|c|}{ 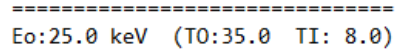 } \\
\hline \multicolumn{6}{|c|}{ *** PUzaf results *** } \\
\hline Na K-ser & @ $3 . \overline{4}$ & 0.99926 & 51.00587 & 1.68 & $61.0^{-}$ \\
\hline Mg K-ser & 0.5 & 1.00296 & 51.01108 & 0.22 & 281.1 \\
\hline Al K-ser & 3.1 & 1.00635 & 1.01979 & 1.16 & 57.4 \\
\hline Y L-ser & 1.0 & 1.01146 & 51.05616 & 0.48 & 199.1 \\
\hline Si K-ser & 8.3 & 1.00947 & 71.03246 & 2.63 & 25.0 \\
\hline K K-alpha & 5.5 & 1.02228 & 1.33975 & 1.06 & 39.6 \\
\hline Ca K-alpha & 379.7 & 1.02442 & 1.00783 & 92.77 & 9.3 \\
\hline standardle & ss & & 43.89 & 100.00 & {$[2 s]$} \\
\hline
\end{tabular}
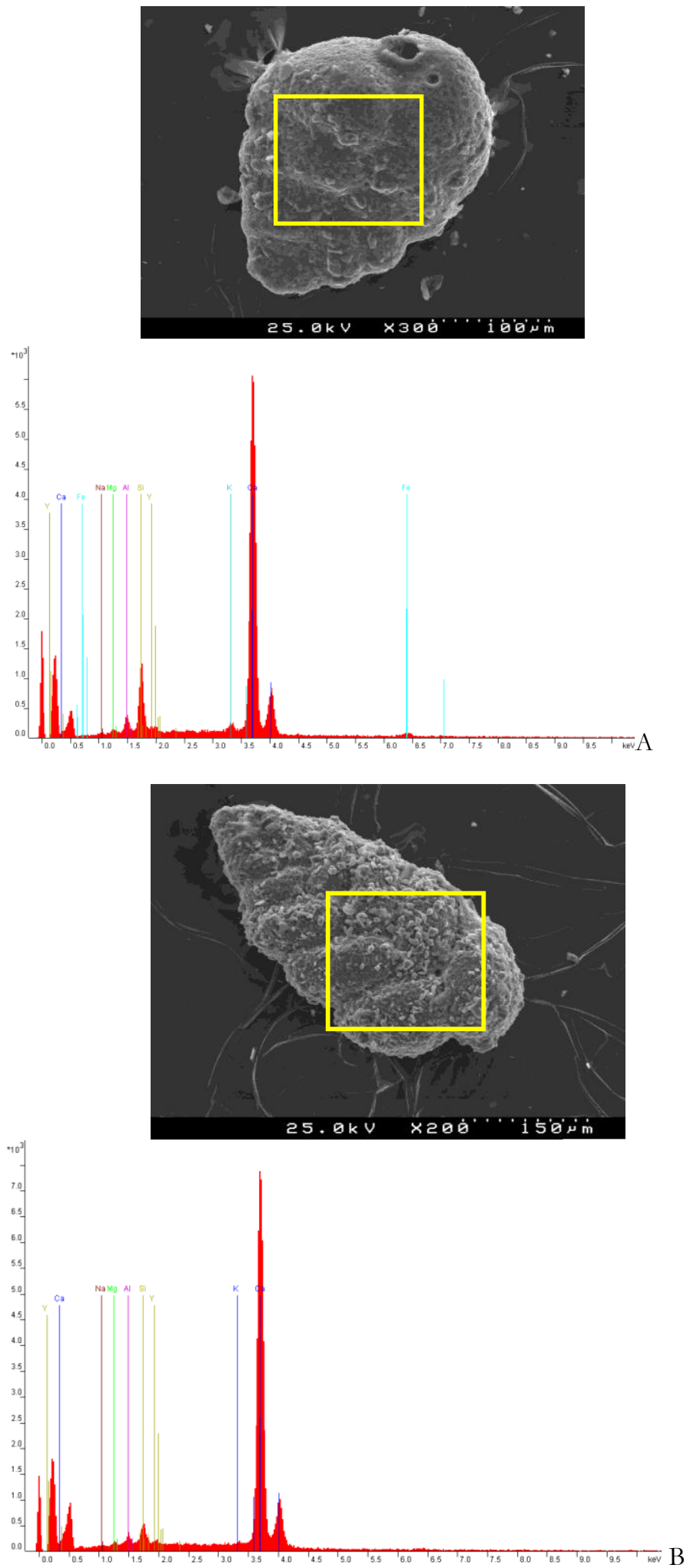

Fig. 5. Results of the EDS Analysis on the SEM of the general composition of the test of: A. Siphotextularia flintii; B. Siphotextularia heterostoma. 


RESULT REPORT X-RAY SPECTROMETRY WITH RONTEC WInTools
Institution:
Operator:
Customer:

\begin{tabular}{|c|c|c|c|c|c|c|c|}
\hline \multirow{3}{*}{\multicolumn{4}{|c|}{ 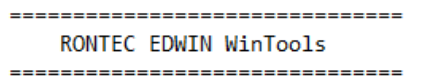 }} & \multicolumn{4}{|c|}{ 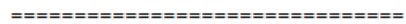 } \\
\hline & & & & G12 29.0 & $7.2016(17$ & $7: 38)$ & \\
\hline & & & & $==0==0==0==$ & $========0$ & $=====$ & \\
\hline \multicolumn{4}{|c|}{ version: 3.1 eng } & Eo: $25.0 \mathrm{keV}$ & (T0: 35.0 & \multicolumn{2}{|c|}{$0 \quad T I:-2.0)$} \\
\hline \multicolumn{8}{|c|}{ *** PUzaf results *** } \\
\hline elem/line & $\mathrm{P} / \mathrm{B}$ & B & $\mathrm{F}$ & $c$ & $c(100 \%)$ & \%error & h \\
\hline Fe K-alpha & $2 . \overline{5}$ & 1.03315 & $1.04 \overline{684}$ & $0 . \overline{24}$ & 0.58 & 123.7 & $<$ \\
\hline $\mathrm{Na} \mathrm{K}$-ser & 4.8 & 0.99931 & 1.00672 & 0.95 & 2.28 & 45.7 & * \\
\hline Mg K-ser & 4.5 & 1.00277 & 1.01219 & 0.74 & 1.78 & 44.1 & * \\
\hline Al K-ser & 12.6 & 1.00595 & 1.01990 & 1.89 & 4.51 & 25.7 & * \\
\hline Si K-ser & 72.5 & 1.00888 & 1.01735 & 9.46 & 22.60 & 16.1 & * \\
\hline $\mathrm{S} \mathrm{K}$-ser & 4.7 & 1.01414 & 1.04647 & 0.50 & 1.18 & 68.4 & \\
\hline K K-alpha & 14.4 & 1.02088 & 1.16638 & 1.30 & 3.11 & 25.4 & \\
\hline Ca K-alpha & 271.0 & 1.02290 & 1.00913 & 26.77 & 63.96 & 11.4 & \\
\hline standardles & & & & 41.86 & 100.00 & {$[2 s]$} & \\
\hline
\end{tabular}

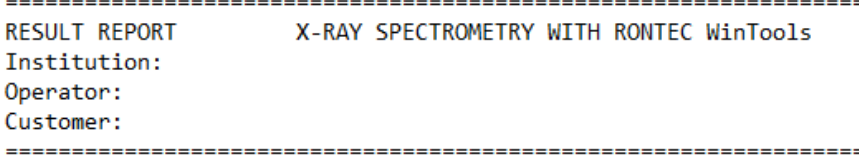
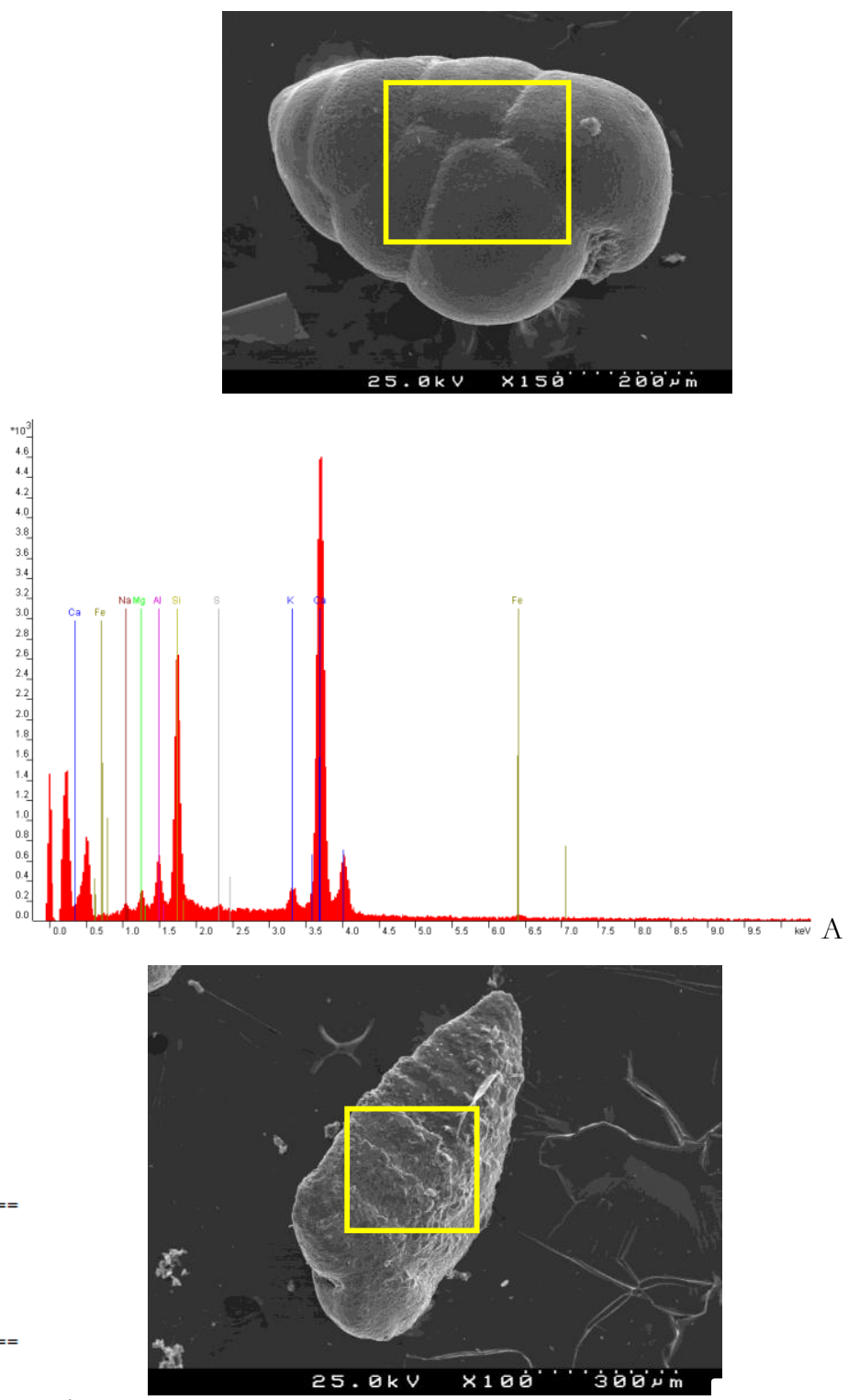

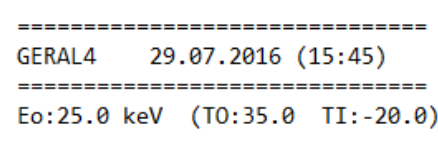

version: 3.1 eng

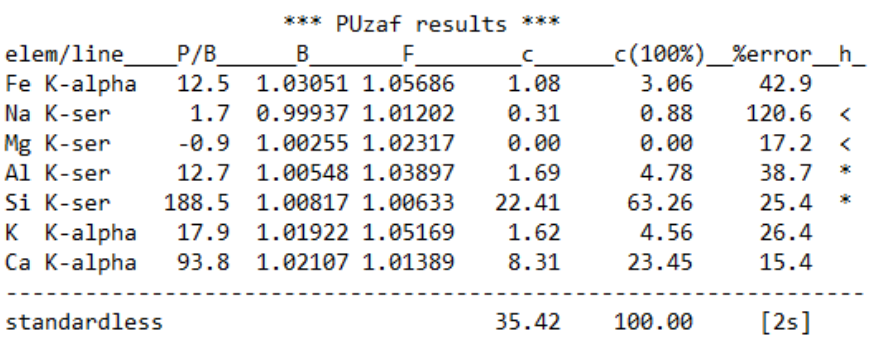

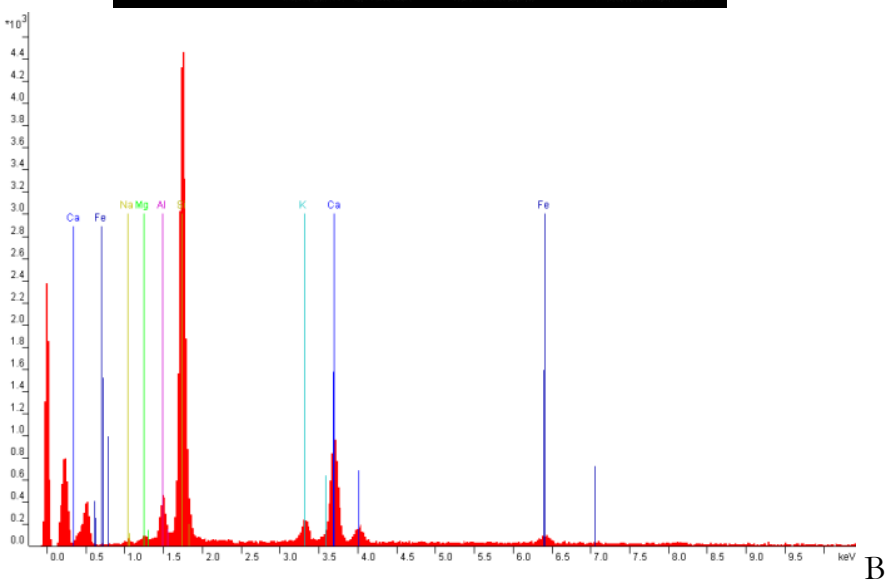

Fig. 6. Results of the EDS Analysis on the SEM of the general composition of the test of: A. Karreriella bradyi; B. Spiroplectammina 


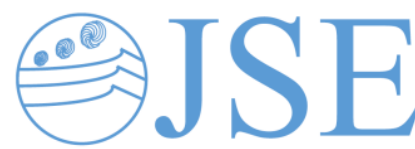

RESEARCH PAPER
Suborder Trochamminina Saidova, 1981

Superfamily Trochamminoidea Schwager, 1877

Family Trochamminidae Schwager, 1877

Subfamily Arenoparellinae Saidova, 1981

Genus Arenoparrella Andersen, 1951

\section{Arenoparrella mexicana (Kornfeld, 1931)}

(Fig. 7)

1931 Trochammina inflata (Montagu) var. mexicana Kornfeld, p. 86; pl. 13, figs $5 \mathrm{a}$, c.

1992 Arenoparrella mexicana (Kornfeld); Brönnimann et al., p. 20; pl. 1, figs 8-10; pl. 13, figs 1-6.

2012 Arenoparrella mexicana (Kornfeld); Debenay, p. 76

Morphological description:

Test trochoid, with a very low trochospira, periphery rounded. Test composed of about three whorls; the last formed coil consisting of five or six chambers; all chambers are visible from the dorsal side, sutures radiate, slightly depressed, nearly straight. Wall finely agglutinated, surface smooth; primary aperture a straight to curved slit surrounded by a thin and delicate lip, begin near the base of the apertural face and is directed upward across the median plane with an angle to the plane of coiling; supplementary openings are present in the final chamber.

EDS Analysis on the SEM

The composition of the test's wall of $A$. mexicana (Fig. 7) includes mostly Si (77.15\%), $\mathrm{Al}(10.60 \%)$ and $\mathrm{K}(7.84 \%)$ and small proportions of $\mathrm{Ca}(1.58 \%), \mathrm{Fe}(1.17 \%), \mathrm{Na}(0.92 \%)$ and $\mathrm{Mg}(0.75 \%)$.

\subsection{Statistical results}

Results of Pearson correlations between the elemental composition of the analyzed specimens are included in Table 2. This table shows, for instance, that: i) A. mexicana and $S$. conica have the lowest correlations with most of the other species; ii) $T$. agglutinans, $K$. flintii, S. beterostoma and $K$. bradyi have high significant positive correlation with the analyzed specimens of $T$. deltoidea and iii) the four analyzed specimens of $T$. deltoidea have strong significant positive correlations among each other.

The CA dendrogram is reported in Figure 8. Based on these results and Pearson correlations, three groups of species can be identified: Group I (T. deltoidea, T. agglutinans, K. flintii and S. beterostoma), Group II (S. conica, S. sagittula and K. bradyi) and Group III (A. mexicana).

\section{Discussion}

\subsection{Ecology and distribution and test composition of the analyzed species and specimens}

\subsubsection{Textularia deltoidea}

This species occurs in all regions and at all depths of the Iberian Continental shelf, with a frequency $<4 \%$ (Levy et al., 1995) such as in the external sector of the Ria de Vigo, NW Spain, at $39 \mathrm{~m}$ (core KSGX 24; Martins et al., 2013); in the Muddy Deposit of Galicia, at 115 m (core KSGX 40; Martins et al., 2006; 2007); in the continental slope of Galicia, at 2,000 $\mathrm{m}$, in the core PE 109-13 (Martins and Gomes, 2004), at the Muddy Deposit of Douro, N of Portugal, at $87 \mathrm{~m}$ (core W90; Martins et al., 2012b); in the W Portuguese continental shelf was identified between 40-190 m with a relative abundance $<2 \%$ (Martins et al., 2012a, 2015a) as well as, in the Gulf of Cadiz, off the Guadiana River, Algarve, it is present in all sectors $(<2 \%)$ of the continental shelf (Mendes et al., 2004). Textularia deltoidea was observed in all regions of the Moroccan continental shelf, being more abundant between $25-150 \mathrm{~m}$. In this zone, it is slightly influenced by the granulometry of the sediment and is associated to salinity (35.9-36.2) and to temperatures of $13-16^{\circ} \mathrm{C}$ (Mathieu, 1986).

The elemental composition indicates that this species builds its test using manly carbonated materials (Figs. 2, 3). The particles added to the wall seems to include cubes of dolomite $\left[\mathrm{CaMg}\left(\mathrm{CO}_{3}\right)_{2}\right]$, bioclasts of other foraminifera and purely carbonated parts and a few lithogenic material (probably quartz and phyllosilicates).

\subsubsection{Textularia agglutinans}

It is a non-symbiont bearing and comparatively large benthic foraminiferal species with a widespread distribution across all oceans. Textularia agglutinans have an epiphytic life mode at natural hard bottom habitats along the Israeli Mediterranean coast, being commonly found attached to stalk or roots of coralline algae or turf's algal substrates (Merkado et al., 2015). This species is rare in the Portuguese continental shelf; only a few occurrences were reported by Levy et al. (1995) and Martins et al. (2015a), in the outer continental shelf.

Living organisms of T. agglutinans were observed in Bay of Biscay in $140 \mathrm{~m}$ depth and the average living depth was $0.6 \mathrm{~cm}$ (Fontanier et al., 2002). In this site the bottom waters are not seriously influenced by the exported organic flux and is characterized by oxygen concentration of $4.9 \mathrm{ml} / 1$ under the influence of Northern Atlantic Central Waters (Fontanier et al., 2002). 


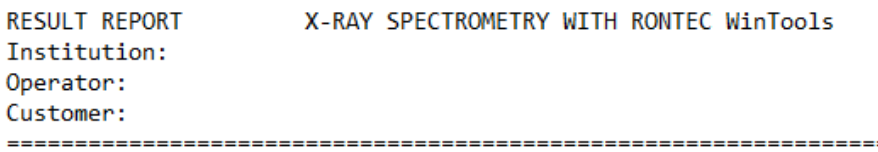

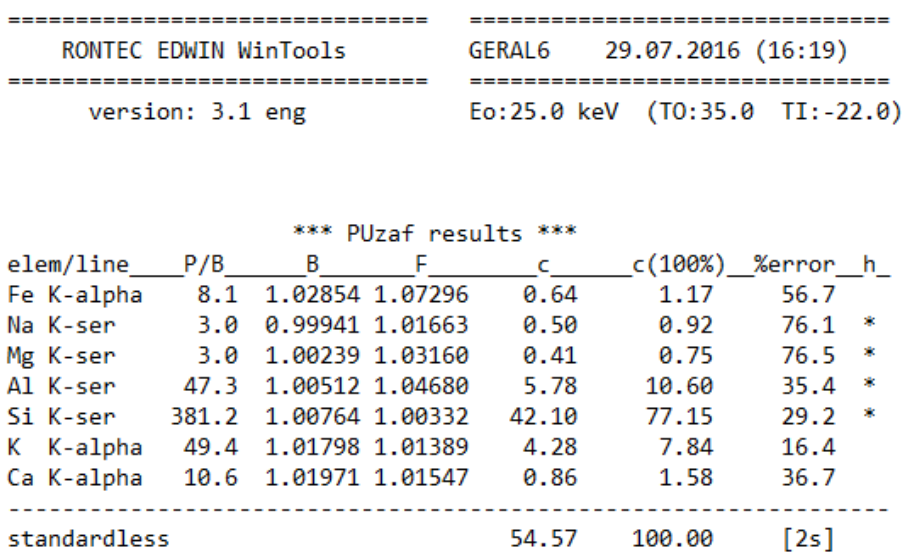
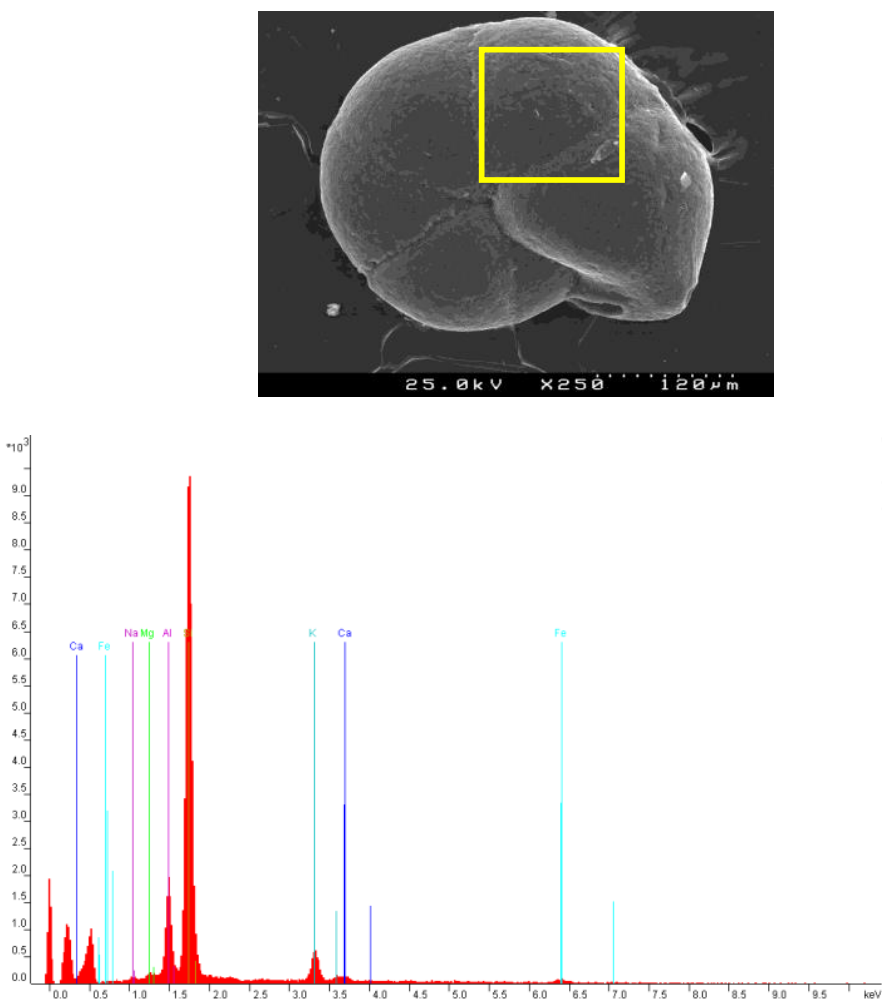

Fig. 7. Results of the EDS Analysis on the SEM of the general composition of the test of Arenoparrella mexicana.

Tab. 2. Pearson correlations between the elemental composition of the analyzed specimens, namely four different specimens of $T$. deltoidea (T. delt.1- T. delt.4) and species. Legend: T. delt. - Textularia deltoidea; T.agglut - Textularia agglutinans S.conica - Sabulia conica; S.sagitt - Spiroplectammina sagittula; K.flintii - Karrerotextularia flintii; S.heter - Siphotextularia heterostoma; K.bradyi - Karreriella bradyi; A.mexic - Arenoparrella mexicana. Significant correlations are marked.

\begin{tabular}{|c|c|c|c|c|c|c|c|c|c|c|c|}
\hline Species & T. delt.1 & T. delt.2 & T. delt.3 & T. delt. 4 & T.agglut & S.conica & S.sagitt & K.flintii & S.heter & K.bradyi & A.mexic \\
\hline T. delt.1 & 1.00 & & & & & & & & & & \\
\hline T. delt.2 & 0.94 & 1.00 & & & & & & & & & \\
\hline T. delt.3 & 0.97 & 0.96 & 1.00 & & & & & & & & \\
\hline T. delt.4 & 0.93 & 0.95 & 0.96 & 1.00 & & & & & & & \\
\hline T.agglut & 0.96 & 0.94 & 0.95 & 0.95 & 1.00 & & & & & & \\
\hline S.conica & 0.61 & 0.66 & 0.69 & 0.63 & 0.67 & 1.00 & & & & & \\
\hline S.sagitt & 0.66 & 0.63 & 0.73 & 0.72 & 0.74 & 0.81 & 1.00 & & & & \\
\hline K.flintii & 0.95 & 0.87 & 0.94 & 0.89 & 0.92 & 0.61 & 0.78 & 1.00 & & & \\
\hline S.heter & 0.95 & 0.83 & 0.89 & 0.84 & 0.86 & 0.53 & 0.62 & 0.93 & 1.00 & & \\
\hline K.bradyi & 0.85 & 0.80 & 0.88 & 0.86 & 0.83 & 0.80 & 0.85 & 0.85 & 0.87 & 1.00 & \\
\hline A.mexic & 0.16 & 0.21 & 0.27 & 0.30 & 0.28 & 0.73 & 0.81 & 0.31 & 0.15 & 0.55 & 1.00 \\
\hline
\end{tabular}

The results of the EDS Analysis on the SEM of the general composition of T. agglutinans (Fig. 4A), evidences that the wall of this species is essentially composed of carbonated particles (Ca 85\%) with the inclusion of a small amount of 


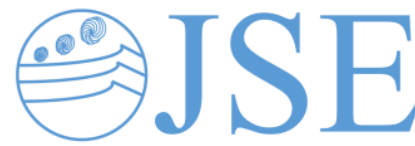

RESEARCH PAPER clay minerals (probably illite, the most abundant clay mineral in the sediments of NW Iberian Margin (Martins et al, $2012 \mathrm{a})$ as suggested by the presence of $\mathrm{Si}(\approx 5 \%), \mathrm{K}(\approx 5 \%)$, $\mathrm{Al}(\approx 3 \%), \mathrm{K}(\approx 2 \%)$ and $\mathrm{Mg}(\approx 1 \%)$.

\subsubsection{Sabulia conica}

It is a cosmopolitan species occurring in neritic and bathyal environments, for example, in the Atlantic and Pacific oceans and in the Mediterranean Sea. Sabulia conica is frequently found in the continental shelf of North America and the Gulf of Mexico (Culver and Buzas, 1982), being abundant in the outer shelf and continental break of Georgia and South Carolina (Arnold, 1983). It dominates (20-25\%) in the bathyal area of California, between 200-2,000 m depth: with temperature ranges from $8.8^{\circ} \mathrm{C}$ at $200 \mathrm{~m}$ and down to $1.8{ }^{\circ} \mathrm{C}$ at $2,000 \mathrm{~m}$ water depth; the oxygen content of 3.6 $\mathrm{ml} / \mathrm{l}$, at $200 \mathrm{~m}$, and $0.4 \mathrm{ml} / \mathrm{l}$ at $660 \mathrm{~m}$, increasing to $3.0 \mathrm{ml} / 1$ at the abyssal zone (Bandy, 1953).

Sabulia conica is common in the circalittoral zone (Pujos, 1976) of the Bay of Biscay, between 60-3,200 m, with frequency $<3 \%$. The highest relative abundance (1.5-3.3\%) of this species was recorded in this region at $135-190 \mathrm{~m}$ (Caralp et al., 1970; Blanc-Vernet et al., 1984).

In the NW Iberian Continental Margin, it normally accounts for $<2 \%$ of the benthic foraminifera assemblages. It was identified in Holocene and Pleistocene sedimentary strata, for instance in the external sector of the Ria de Vigo, NW of Spain, $39 \mathrm{~m}$ deep (core KSGX 24; Martins et al, 2013); in the Muddy Deposit of Galicia, at $115 \mathrm{~m}$ (core KSGX 40; Martins et al., 2006; 2007); in the continental slope of Galicia, at 2,000 m, in the core PE 109-13 (Martins and Gomes, 2004); in the Douro Muddy Deposit, N of Portugal, at $87 \mathrm{~m}$ (core W90; Martins et al., 2012b). Sabulia conica occurs in the Portuguese continental shelf (Levy et al., 1995): it is common $(<4 \%)$ in the western Atlantic Margin (Martins et al., 2012a, 2015a) and in Gulf of Cadiz, off the Guadiana River, Algarve (Mendes et al., 2004).

According to Arnold (1983), the wall of the test of S. conica is constructed almost exclusively by terrigenous material, and therefore, the distribution of these components in the sediments is one of the factors that regulates the occurrence of this species. Species that agglutinate terrigenous materials are generally rare where the abundance of these components is reduced (Arnold, 1983).

The results of the EDS on SEM of this work also indicates that the test's wall of $S$. conica includes mostly lithogenic particles but also some carbonated material. The lithogenic component should contain aluminosilicates, such as microcline $\left(\mathrm{KAlSi}_{3} \mathrm{O}_{8}\right)$, orthoclase $\left(\mathrm{KAlSi}_{3} \mathrm{O}_{8}\right)$, lepidolite $\left(\mathrm{K}(\mathrm{Ii}, \mathrm{A})_{3}(\mathrm{Si}, \mathrm{Al}) 4 \mathrm{O}_{10}(\mathrm{~F}, \mathrm{OH})_{2}\right), \quad$ muscovite $\left(\mathrm{KAl}_{2}\left(\mathrm{Si}_{3} \mathrm{~A}\right) \mathrm{O}_{10}(\mathrm{OH}, \mathrm{F})_{2}\right)$, biotite $\left(\mathrm{K}\left(\mathrm{Mg}, \mathrm{Fe}^{++}\right)_{3}\left[\mathrm{AlSi}_{3} \mathrm{O}_{10}(\mathrm{OH}, \mathrm{F})_{2}\right)\right.$ and illite $\left(\mathrm{K}, \mathrm{H}_{3} \mathrm{O}\right)(\mathrm{Al}, \mathrm{Mg}, \mathrm{Fe})_{2}\left(\mathrm{Si}, \mathrm{Al}_{4} \mathrm{O}_{10}\left[(\mathrm{OH})_{2},\left(\mathrm{H}_{2} \mathrm{O}\right)\right]\right.$. The wall of $S$. conica also includes a small proportion of $\mathrm{S}$.

However, the proportion of $\mathrm{K}$ in the mentioned minerals is inferior to that found in the wall of $S$. conica. Potassium levels influence multiple physiological processes, including the transport of substances through the cellular-membrane, acid-base homeostasis fluid and electrolyte balance (Solomon, 1962; Kernan, 1980; Hellgren et al., 2006, Lockless et al., 2007; Malnic et al., 2013).

Sulfur is an essential element for all life. It commonly occurs in the form of organosulfur compounds or metal sulfides. Some amino acids, vitamins, as cofactors, disulfides, S-S bonds, confer mechanical strength and insolubility to proteins such as keratin. Sulfur is also one of the core chemical elements needed for biochemical functioning and is an elemental macronutrient for all organisms.

\subsubsection{Karrerotextularia flintii}

This species was recorded in some stations along all the Portuguese continental shelf (Levy et al., 1995), Southwestern Pacific: New Caledonia, northern shelf, $600 \mathrm{~m}$ (Debenay, 2012). According to Debenay (2012), this species agglutinates the particles using a carbonate cement. The results of the EDS analysis on the SEM (Fig. 5A) evidence that the wall is essentially composed of carbonated particles also including some lithogenic component namely phyllosilicates and feldspars. Ytrium concentrations are relatively high in the test's wall of this species.

\subsubsection{Siphotextularia heterostoma}

This species was identified in the upper slope off Aveiro (465 m deep; Appendix 1). The results of the EDS analysis (Fig. 5B) suggest that this species mainly agglutinates carbonated material and a small lithogenic component.

No iron was identified in the test's wall of $S$. heterostoma. The elemental composition of the wall of this species (mainly composed by $\mathrm{Ca}$ and small proportion of $\mathrm{Si}, \mathrm{Na}, \mathrm{Al}$, and $\mathrm{K}$ ) indicates that it should include mostly muscovite $\left[\mathrm{KAl}_{2}\left(\mathrm{Si}_{3} \mathrm{Al}\right) \mathrm{O}_{10}\left(\mathrm{OH}, \mathrm{F}_{2}\right]\right.$ and plagioclase (calcosodic series) and a few dolomite and/or magnesite particles that are common in the sediments of Iberian Margin (Martins et al., 2012a).

S. heterostoma species wall is grainy; the grains are irregular in size and shape. Most of the grains are probably carbonated and seem to be agglutinated with a carbonated cement. 


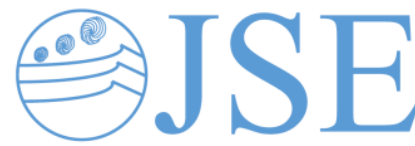

RESEARCH PAPER

\subsubsection{Karreriella bradyi}

Karreriella bradyi is a shallow infaunal (Fontanier et al., 2002), bahyal species, common in the Pacific (Murray, 1991), for instance in New Caledonia at $600 \mathrm{~m}$ water depth (Debenay, 2012) and in the Southwest region of the Indian Ocean (Corliss, 1979). It is commonly collected in the North American continental margin, as well as in the Gulf of Mexico (Culver and Buzas, 1982; Robertson, 1998), in the outer continental shelf and slope and abyssal plain (Culver and Buzas, 1983).

Karreriella bradyi is a rare species on the Portuguese continental shelf (Levy et al., 1995) and presents in the Quaternary sedimentary strata $(<1 \%)$ of the Galicia continental slope ( $\mathrm{N}$ Spain), at 2,000 $\mathrm{m}$ water depth (in core PE 109- 13; Martins and Gomes, 2004) and in core KSGX24, at $2765 \mathrm{~m}$ water depth (Appendix 1). According to Cushman (1911), the finely agglutinated test's wall of $K$. bradyi is composed of arenaceous or calcareous materials. The results of the EDS analysis on the SEM (Fig. 6A) agree with this description. Like $S$. conica, the wall of this species also includes significant proportion of $\mathrm{K}$ and $\mathrm{S}$ and has similar characteristics to those observed in $S$. conica.

\subsubsection{Spiroplectammina sagittula}

The assemblage of $S$. sagittula has been identified in the European and African continental margin, in several places, between 20-600 $\mathrm{m}$ deep, in muddy substrates and sandy muds; in temperatures between $7-16^{\circ} \mathrm{C}$ and; salinities of $35-$ 36.5 (Murray, 1991, Debenay and Basov, 1993). It dominates on sandy substrates between $51-59 \mathrm{~m}$ depth in the Eddysttone-Plymouth region and between $84-95 \mathrm{~m}$ in the Channel of England (Murray, 1970). It is related to fine grained sediments in the Celtic Sea (Le Calvez, 1958).

Spiroplectammina sagittula is frequent in the continental shelf of the South of Gascon, from 40-60 m, where it is very abundant in sandy substrates (Pujos, 1976). It is well represented in the North of Spain, in shallow muddy bottoms, in the Cantabria and Galician regions (Colom, 1974). It only represents a proportion $<1 \%$ in Baiona Bay and Ria de Vigo (Alejo et al., 1999), as well as in Holocene and Pleistocene strata: in the Douro Muddy Deposit, $\mathrm{N}$ of Portugal, at $87 \mathrm{~m}$ (core W90; Martins et al., 2012b); in the Galicia Muddy Deposit, $115 \mathrm{~m}$ deep (core KSGX 40; Martins et al., 2006; 2007); in the continental slope of Galicia, at 2,000 m (core PE 109-13; Martins and Gomes, 2004).

Spiroplectammina sagittula is quite common in other regions of Portuguese continental shelf (Levy et al., 1993), in areas with depths >50 m (Galhano, 1963; Martins et al., 2012a, 2015a). In Gulf of Cadiz, southern Spain, in the zone between the mouth of the Guadalquivir River and Cape Trafalgar, S. sagittula was found $(<2.5 \%)$ in sandy and sandymud sediments between 50-500 m (Guimerans et al., 1999).

In the Spanish Mediterranean, S. sagittula is common in muddy bottoms of the Catalan coast, between $70-100 \mathrm{~m}$ (Mateu, 1970), and between 50-200 m, on the coast of Nerja and Montril (Sánchez Ariza, 1983). It also occurs in other parts of the Mediterranean Sea, such as the Gulf of Ajaccio, where it is most abundant in fine sediments between 150$200 \mathrm{~m}$ (Bizon and Bizon, 1984), and in the upper continental slope of the Adriatic Sea (Jörissen, 1987; Stigter et al., 1998).

The highest abundance of living organisms of $S$. sagittula has been found in the superficial sediments $(0-0.5 \mathrm{~cm}$; Stigter et al., 1998, Fontanier et al., 2002). This species can however penetrate the sediment up to $5 \mathrm{~cm}$ below the surface, as observed by Stigter et al. (1998).

The wall of $S$. sagittula is rich in $\mathrm{Ca}, \mathrm{Si}$ and $\mathrm{Al}$ also including $\mathrm{K}, \mathrm{Na}, \mathrm{Mg}, \mathrm{S}$ and $\mathrm{Fe}$ (Fig. $6 \mathrm{~B}$ ), which may indicate that this species essentially includes carbonated materials with significant amount of lithogenic particles.

\subsubsection{Arenoparrella mexicana}

Arenoparrella mexicana is dominant or common in coastal transitional areas with low salinity occurring for instance in mangrove swamps and marshes (Debenay, 2012; Martins et al., 2015b). The wall of this species (Fig. 7) is essentially composed of fine sand particles grains (lithoclastic materials) probably including quartz grains, plagioclase, $\mathrm{K}$-feldspar and phyllosilicates.

\subsection{Comparison between the analyzed species}

The cluster analysis results (Fig. 8), correlations (Table 2) and the elemental composition of the test's wall of the analyzed specimens allowed to verify gradients of elements enrichment. The species of Group I, T. deltoidea, $T$. agglutinans, $K$. flintii and $S$. heterostoma, are characterized by the highest concentrations of $\mathrm{Ca}, \mathrm{Mg}$ and $\mathrm{Y}$ and the lowest $\mathrm{Si}$ and $\mathrm{Al}$ contents. The species of Group II, S. conica, S. sagittula and $K$. bradyi, present intermediate concentrations of these elements but display the highest $\mathrm{K}$ content. Group III, represented by $A$. mexicana, contains the highest $\mathrm{Si}$ and $\mathrm{Al}$ contents and the lowest $\mathrm{Ca}, \mathrm{Mg}$ and $\mathrm{Y}$ concentrations.

According to Nørvang (1966), the Textulariida (SubClass) includes organisms with calcarenitic and arenitic wall. The tests' particles are cemented by low-Mg calcite (Sen Gupta, 1999). It is not known how much Ca is being retained in the composition of the cement used to build the test. 
The species with a test's wall with low amount of Ca (1.58 $\%)$ is $A$. mexicana. This species is typical of hypohalinebrackish $(0.5-9.5 \%$ ) waters in transitional environments such as lagoon systems and mangrove swamps intersected by small rivers and tidal creeks (Semensatto-Jr and Dias-Brito, 2004) and estuaries (Camacho et al., 2015; Murray, 2006).

The Ca content should be used in the cement and is probably related to the mineralogical composition of the particles agglutinated by this organism, such as plagioclase that is present in the sediments composition (4.2\%; Appendix 2).

The localities where this species was collected has normally low TOC content but relatively low $\mathrm{pH}$ value (7.4; Appendix 2). It is known that below 7.6, the $\mathrm{pH}$ is a stressing factor for calcareous benthic foraminifera. These conditions may not be favorable to the production of a thick layer of carbonate cement and this species probably use the available lithological component present in the environment such as quartz, phyllosilicates, plagioclase and K-feldspars.
Regardless of the amount of Ca present in the cement of the test's wall, the species of Group 1 essentially use carbonated particles to build their tests. The particles (38-49\%) seem to be abundant in the localities where the analyzed species were collected (Appendix 2).

The specimen 1 of $T$. deltoidea seems to present structures that may be composed by $100 \%$ carbonate or constituted by magnesium carbonate (dolomite). Dolomite is relatively abundant in the localities where this specimen was collected (12\%, Appendix 2) as well as carbonates. The test's wall of the species of Group 2 displays relatively high $\mathrm{K}$ content, namely in S. conica (K: $23.03 \%$ ). In these species were also found significant $\mathrm{S}$ concentrations $(2.3 \%)$.

As mentioned $\mathrm{K}$ is an essential chemical element that regulates important cellular activities (Solomon, 1962; Kernan, 1980; Hellgren et al., 2006; Lockless et al., 2007; Malnic et al., 2013) as well as S that may have an important structural function.

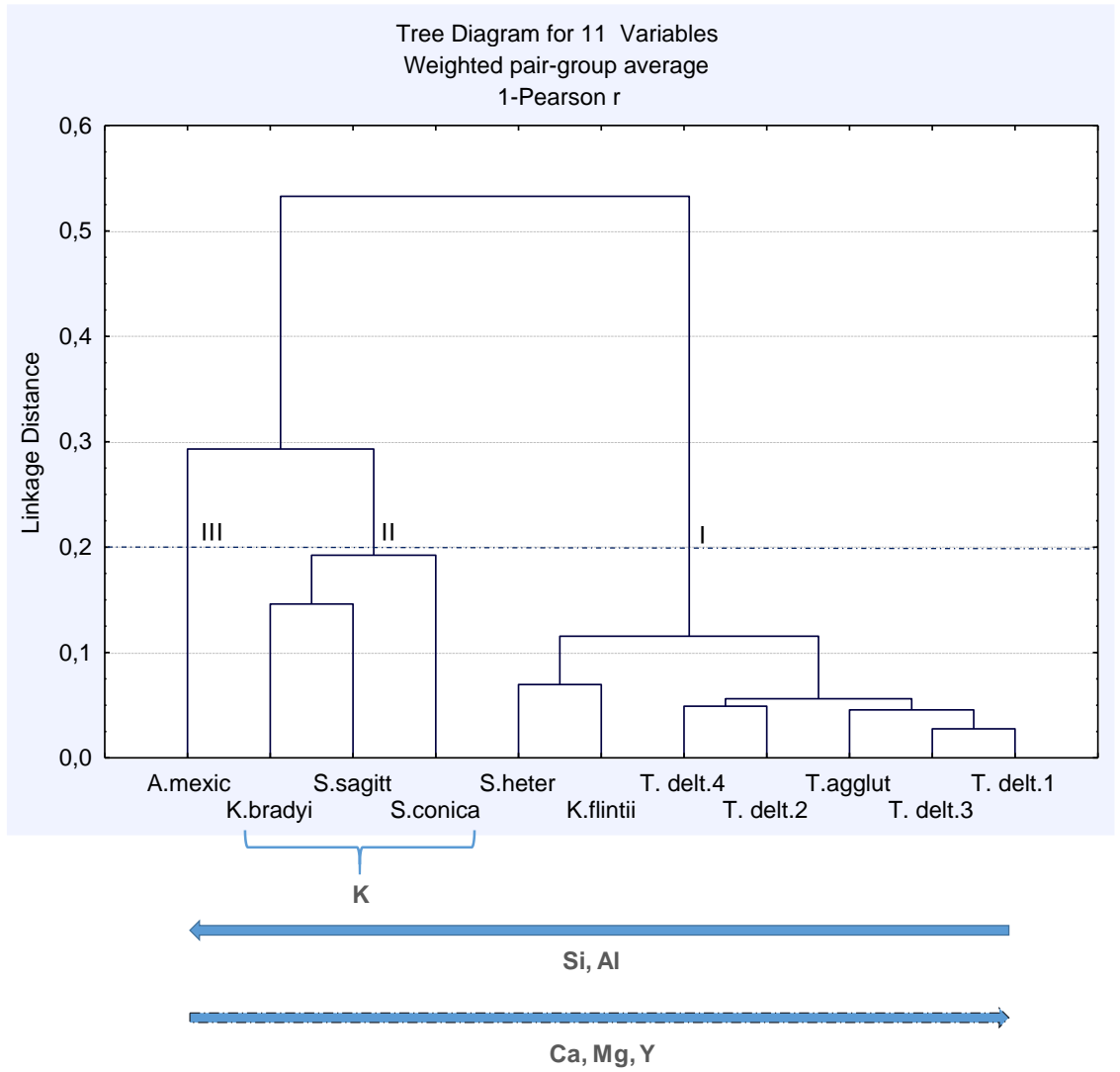

Fig. 8. Grouping of species by Cluster Analysis based on the elemental composition of the test's wall of the analyzed specimens, namely four different specimens of T. deltoidea (T. delt.1- T. delt.4). Legend: T. delt. - Textularia deltoidea; T.agglut - Textularia agglutinans S.conica - Sabulia conica; S.sagitt - Spiroplectammina sagittula; K.flintii - Karrerotextularia flintii; S.heter - Siphotextularia heterostoma; K.bradyi - Karreriella bradyi; A.mexic - Arenoparrella mexicana. 
As hypothesized by Lovelock (1979) foraminifera may use "storage" and "excretion" as functions of biomineralization. According to this author whereas some useful minerals which are undersaturated in the milieu (such as silica and apatite for planktonic foraminifera) would be concentrated in the biosphere, whereas supersaturated minerals may be toxic (such as calcium carbonate) being "pumped down". On the other hand, $\mathrm{CaCO}_{3}$ often reaches supersaturated conditions, especially in shallow shelf seas. In such environments $\mathrm{Ca}^{++}$has a tendency to enter in the cells and becomes toxic (Simkiss, 1977)

Thus the mechanism of biomineralization can pump it out some toxic or useless chemical elements at a given moment so they can be used when needed. Skeletons provide a protective envelope that can be adapted toward more specific ends, such as passive regulation of buoyancy, storage of silica or other chemical elements, and excretion of toxic calcium (Brasier, 1986).

\section{Conclusion}

The results of this work indicate that the main constituent of the wall of $T$. deltoidea, $T$. agglutinans, $K$. flintii and $S$. heterostoma tests are carbonate particles whereas Sabulia conica, Karreriella bradyi, Spiroplectammina sagittula include significant amount of lithogenic particles in the wall. The test composition of $A$. mexicana is essentially composed by lithogenic particles with low abundance of a carbonated cement. Thus carbonates are the main constituent both in mainly siliciclastic sediments and in the deep sea where the sediments ae composed mainly by a carbonated oose. The inverse also was observed. Karreriella bradyi for instance a quite common species in the deep sea in essentially carbonated sediments, select a relatively high amount of silisiclastic materials.

There are some evidences that at least $T$. deltoidea may segregate some carbonated particles that are used in its test building. Sabulia conica, K. bradyi, and S. sagittula should also use the wall to accumulate some elements that they can use again to regulate the fluids of the cell or to vital functions if necessary. Textulariids also should use the text to pump toxic elements if they are retained by the cell in high concentrations. "Storage" and "excretion" seems to be functions of biomineralization of some Textulariid species.

Acknowledgment

This work was supported by funds of the UID/GEO/04035/2013 (FCT, Portugal).
Appendices 1 and 2 are attached as supplementary materias (SM1SM2) in http://www.epublicacoes.uerj.br/index.php/jse/article/view/26888

\section{References}

Alejo, I., Austin, W. E. N., Francés, G., Villas, F., 1999. Preliminary investigations of the recent foraminifera of Baiona Bay, NW Spain. Journal of Coastal Research 15 (2), 413-427.

Alve, E., Murray, J.W., 1995. Experiments to determine the origin and palaeoenvironmental significance of agglutinated foraminiferal assemblages. In Kaminski, M.A., Geroch, S. and Gasiński, M.A. eds., Proceedings of the Fourth International Workshop on Agglutinated Foraminifera: Grzybowski Foundation Special Publication 3, 1-11.

Andersen, H.V., 1951. Two new genera of foraminiferal from Recent deposits in Luisiana. Journal of Paleontology, Published by SEPM Society for Sedimentary Geology 25 (1), 31-34

Arnold, A.J., 1983. Foraminiferal thanatocoenoses on the continental slop off Georgia and South Carolina. Journal of Foraminiferal Research 13 (2), 79-90.

Bandy, O.L., 1953. Ecology and paleoecology of some California foraminifera. Part I. The frequency distribution of recent Foraminifera off California. Journal of Paleontology 27 (2), pt. 1, 161-182, pl. 21-25.

Bender, H., Hemleben, C., 1988. Constructional aspects in test formation of some agglutinated foraminifera. Abhandlungen der Geologischen Bundesanstalt 41, 13-12.

Bizon, G., Bizon, J.J., 1984. Distribution des foraminiferes dans le Golfe d' Ajaccio. In Bizon, J.J. and Burollet, P.F. (eds.), Ecologie des microorganismes en Meditterranée occidentale (ECOMID), Association Francaise Technology Petroleum, pp. 95-104.

Blanc-Vernet, L., Pujos, M., Rosset Moulinier, M., 1984. Les biocénoses de foraminifères benthiques des plateaux continentaux français (Manche, Sud-Gasconhe, OuestProvence). In Oertli, H.J. (ed.), Benthos'83, 2e Symposium International sur les Foraminifères Benthiques, Pau (France), 71-79.

Brasier, M., 1986. Why do lower plants and animals biomineralize? Paleobiology 12(3), 241-250.

Brönnimann, P., Whittaker, J.E., Zaninetti, L., 1992. Brackish water foraminifera from mangrove sediments of southwestern Viti Levu, Fiji Islands, southwest Pacific. Revue de Paléobiologie, 11, 13-65.

Camacho, S. G., Moura, D.J.M., Connor, S., Scott, D.B., Boski, T., 2015. Taxonomy, ecology and biogeographical trends of dominant benthic foraminifera species from an AtlanticMediterranean estuary (the Guadiana, southeast Portugal). Palaeontologia Electronica 18.1.17A, 1-27. palaeoelectronica.org/content/2015/1106-estuarine-forams-fromiberia 
Caralp, M., Lamy, A., Pujos, M., 1970. Contribution a la connaissance de la distribution bathymetrique des foraminiferes dans le Golfe de Gascogne. Revista Española de Micropaleontología 2 (1), 55-84.

Colom, G., 1974. Foraminiferos Ibericos. Intruducción al estudio de las espécies bentónicas recientes. Investigacion Pesquera, Consejo Superior de Investigaciones Científicas. Patrono Juán de la Cierva, Barcelona, t. 38 (1), 245 pp.

Corliss, B.H., 1991. Morphology and microhabitat preferences of benthic foraminifera from the northwest Atlantic Ocean. Marine Micropalaeontology 17, 195-236.

Culver, S.J., Buzas, M.A., 1983. Recent benthic foraminifera provinces in the Gulf of Mexico. Journal of Foraminiferal Research 13 (1), 21-31.

Culver, S.J., Buzas, M.A., 1982. Recent benthic foraminiferal provinces between Newfoundland and Yucatan. Geological Society of America Bulletin 93, 269-277.

Corliss, B.H., 1979. Taxonomy of recent deep-sea benthonic foraminifera from the Southeast Indian. Ocean. Micropaleontology 25 (1), 1-19.

Cushman, J.A., 1937. A Monograph of the Foraminiferal Family Verneuilinidae. Contributions of Cushman Laboratory of Foraminifera Research, Sharon, Massachusetts, U.S.A., Special Publication, n. ${ }^{\circ} 7$.

Cushman, J.A., 1933. Some new Recent foraminifera from the tropical Pacific. Contributions from the Cushman Laboratory for Foraminiferal Research 9, 77-95.

Cushman, J.A., 1927. An outline of a re-classification of the foraminifera. Contributions of Cushman Laboratory of Foraminifera Research, Sharon, Massachusetts, U.S.A., vol. 3.

Cushman, J.A., 1911. A monograph of the foraminiferal of the North Pacific Ocean; Part II - Textulariidae. Bulletin of United States National Museum, D.C., U.S.A., n. ${ }^{\circ} 71$.

d'Orbigny, A., 1839. Foraminifères. In Ramon de la Sagra, Histoire physique, politique et naturelle de l'ile de Cuba. A. Bertrand, Paris, France, p. 144, vol. 8.

d'Orbigny, A., 1826. Tableau methodique de la classe des Cephalopodes. Annales des Sciences Naturelles 7, 245-314.

Debenay, J.-P., 2012. A Guide to 1,000 Foraminifera from Southwestern Pacific: New Caledonia. Publications Scientifiques du Muséum national d'Histoire Naturelle, Paris.

Debenay, J-P., Basov, I., 1993. Distribution of recent benthic foraminifera on the West African shelf and slope. A synthesis. Revue de Paléobiologie 12 (1), 265-300.

Defrance, M., Blainville, H., 1824. Mollusques, vers et zoophytes. Dictionnaire des Sciences Naturelles Blainville H.M.D. de, Strasbourg, Paris, F.G. Levrault, 32.

Delage Y, Hérouard, E. 1896. Traité de zoologie concrète: La cellule et les protozoaires. Paris: Schleicherfrères. doi.org/10.5962/bhl.title.11672
Ehrenberg, C., 1839. Über die Bildung der Kreidefelsen und des Kreidemergels durch unsichtbare Organismen. physikalische abhandlungen der Koniglichen akademie der wissenschaften zu Berlin. Berlin: physikalische abhandlungen der Koniglichen akademie der wissenschaften zu Berlin.

Finlay, H.J., 1939. New Zealand foraminifera: key species in stratigraphy, n. ${ }^{\circ} 1$. Transactions of the Royal Society of New Zealand, vol. 68.

Flint, J.M., 1899. Recent foraminifera. A descriptive catalogue of specimens dredged by the U.S. Fish Commission Steamer Albatros. Report of the United States National Museum for 1897, 249-349.

Fontanier, C., Jorissen, F.J., Licari, L., Alexandre, A., Anschutz, P., Carbonel, P., 2002. Live benthic foraminiferal faunas from the Bay of Biscay: faunal density, composition, and microhabitats Deep-Sea Research I 49, 751-785.

Fornasini, C., 1896. Ottavo Contributo alla conoscenza della microfanna terziarii. Italiana - Memorie dell'Accademia della Scienze dell'Istituto di Bologna 5/6.

Galhano, M.H., 1963. Foraminíferos da Costa de Portugal (Algarve). Publicações do Instituto de Zoologia Dr. Augusto Nobre, Faculdade de Ciências do Porto, 110 pp.

Gaucher, C., Sprechmann, P., 1999. Upper Vendian skeletal fauna of the Arroyo de Soldado Group, Uruguay. Beringeria 23, 55-91.

Guimerans, P.V., Sanagustín, J.I.C., Currado, J.L.C., 1999. Los foraminíferos bentónicos Textulariina en los sedimentos superficiales del margem septentrional del Golfo de Cádiz (España). Revista Española de Microplaeontología 31 (2), 243 253.

Hayward, B., 2013. Textulariia. In: Hayward, B.W., Cedhagen, T., Kaminski, M., Gross, O., 2016. World Foraminifera Database. Accessed http://www.marinespecies.org/foraminifera/aphia.php?p=taxd etailsandid $=736978$ on 2016-12-30.

Hellgren, M., Sandberg, L., Edholm, O., 2006. A comparison between two prokaryotic potassium channels (KirBac1.1 and $\mathrm{Kcs} A$ ) in a molecular dynamics (MD) simulation study. Biophysical Chemistry 120 (1), 1-9. doi:10.1016/j.bpc.2005.10.002.

Jones, R.W., 1994. The Challenger Foraminifera. The Natural History Museum, London, Oxford University Press, 150 pp.

Jörissen, F.J., 1987. The distribution of benthic foraminifera in the Adriatic Sea. Marine Micropalaeontology 12, 21-48.

Kaminski, M.A., 2004. The Year 2000 Classification of the Agglutinated Foraminifera. In: Bubík, M. and Kaminski, M.A. (eds), 2004. Proceedings of the Sixth International Workshop on Agglutinated Foraminifera. Grzybowski Foundation Special Publication 8, 237-255.

Kaminski, M.A., Kuhnt, W., 1995. Tubular agglutinated foraminifera as indicators of organic carbon flux. In Kaminski, M.A. Geroch, S. and Gasinski, M.A. (eds.), Proceedings of the 
Fourth International Workshop on Agglutinated Foraminifera: Grzybowski Foundation Special Publication 3, 141-144.

Kaminski, M.A., Boersma, A., Tyszka, J., Holbourn, A.E.L., 1995. Response of deep-water agglutinated foraminifera to dysoxic conditions in the California Borderland basins. In Kaminski, M.A. Geroch, S. and Gasinski, M.A. (eds.), Proceedings of the Fourth International Workshop on Agglutinated Foraminifera: Grzybowski Foundation Special Publication 3, 131-140.

Kernan, R.P., 1980. Cell potassium (Transport in the life sciences). New York: Wiley, 200 pp.

Kornfeld, M.M., 1931. Recent littoral foraminifera from Texas and Louisiana. Contributions from the Department of Geology of Stanford University 1, 77-101.

Lankester, E.R., 1885. Protozoa. In Encyclopaedia Britannica, 19, $19^{\text {th }}$ ed., p. $830-866$.

Le Calvez, Y., 1958. Les Foraminifères de la Mer Celtique. Revue Revue des travaux de l'Institut des pêches maritimes, France, 6 (1), 41-50.

Le Calvez, Y., de Klasz, I., Brun, L., 1974. Nouvelle contribution a al connaissance des microfaunes du Gabon. Revista Española de Micropaleontología 6, 381-400.

Levy, A., Mattieu, R., Poignant, A., Rosset-Moulinier, M., Ubaldo, M., Lebreiro, S., 1995. Foraminifères Actuels de la Merge Continental Portuguaise - Inventaire et Distribuicion. Memórias do Instituto Geológico e Mineiro, 32, Lisboa.

Levy, A., Mathieu, R., Poignant, A., Rosset-Moulinier, M., Ubaldo, M.L., Ambroise, D., 1993. Recent foraminifera from the continental margin of Portugal. Micropaleontology 39, 75-87.

Lockless, S.W., Zhou, M., MacKinnon, R., 2007. Structural and thermodynamic properties of selective ion binding in a $\mathrm{K}+$ channel. PLoS Biol 5 (5), e121. doi:10.1371/journal.pbio.0050121.

Loeblich, A.R. Jr, Tappan H., 1994. Foraminifera of the Sahul Shelf. Cushman Foundation for Foraminiferal Research, Special Publication 31, 1-661.

Loeblich, A.R., Tappan, H., 1989. Implications of wall composition and structure in agglutinated Foraminifera. Journal of Paleontology 36, 769-777.

Loeblich, A.R., Jr. and Tappan, H., 1987. Foraminiferal genera and their classification. 2 volumes, New York, Van Nostrand Reinhold, 970 pp.

Loeblich, A. R. Jr., Tappan, H., 1985. Some new and redefined genera and families of agglutinated foraminifera; I. Journal of Foraminiferal Research 15 (2), 91-104._doi: 10.2113/gsjfr.15.2.91

Lovelock, J., 1979. Gaia. A New Look at Life on Earth. Oxford Univ. Press; Oxford.

Malnic, G., Giebisch, G., Muto, S., Wang, W., Bailey, M.A., Satlin, L.M., 2013. Regulation of K+ excretion. In: Alpern, R.J., Caplan, M.J., Moe, O.W., eds. Seldin and Giebisch's the kidney: physiology and pathophysiology. 5th ed. London: Academic Press, 1659-1716
Margulis, L., Schwartz, K.V., 1998. Five Kingdoms: an illustrated guide to the Phyla of life on earth. 3rd edition. Freeman: New York, NY (USA). ISBN 0-7167-3027-8. xx, 520 pp.

Martins, M.V.A., Quintino, V., Tentúgal, R.M., Frontalini, F., Miranda, P., Laut, L.L.M., Martins, R., Ana Maria Rodrigues, A.M., 2015a. Characterization of bottom hydrodynamic conditions on the central western Portuguese continental shelf based on benthic foraminifera and sedimentary parameters Marine Environmental Research, 109, 52-68. doi.org/10.1016/j.marenvres.2015.06.006

Martins, M.A.V., Silva, F., Laut, L.M.L., Frontalini, F., Clemente, I.M.M.M., Miranda, P., Figueira, R., Sousa, S.H.M., Dias, J.M.A., 2015b. Response of benthic foraminifera to organic matter quantity and quality and bioavailable concentrations of metals in Aveiro Lagoon (Portugal). PLoS ONE 10 (2): e0118077. doi:10.1371/journal.pone.0118077

Martins, V., Rocha, F., Sequeira, C., Martins, P., Santos, J., Dias, J.A., Weber, O., Jouanneau, J.-M., Rubio, B., Rey,D., Bernabeu, A., Silva, E., Laut, L., Figueira, F., 2013. Late Holocene climatic oscillations traced by clay mineral assemblages and other paleoceanographic proxies in Ria de Vigo (NW Spain). Turkish Journal of Earth Sciences, 22, 398-413. doi:10.3906/yer-1112-12.

Martins, V., Abrantes, I., Grangeia, C., Martins, P., Nagai, R., Sousa, S.H.M., Laut, L.L.M., Dias, J.M.A., Ferreira da Silva, E., Rocha, F., 2012a. Records of sedimentar dynamics in the continental shelf and upper slope between Aveiro-Espinho (N Portugal). Journal of Marine Systems, 96, 48-60. doi: 10.1016/j.jmarsys.2012.02.001.

Martins, V., Figueira, R., França, E.J., Ferreira, P.A.L., Martins, P., Santos, J.F., Dias, J.A., Laut, L.L.M., Monge Soares, A., Ferreira da Silva, E., Rocha, F., 2012b. Sedimentary Processes on the NW Iberian Continental Shelf since the Little Ice Age. Estuarine, Coastal and Shelf Science 102, 48-59. doi: 10.1016/j.ecss.2012.03.004

Martins, V., Dubert, J., Jouanneau, J.-M., Weber, O., Ferreira da Silva, E., Patinha C., Dias, J.M.A, Rocha, F., 2007. A multiproxy approach of the Holocene evolution of shelf-slope circulation on the NW Iberian Continental Shelf. Marine Geology 239, $1-$ 18. doi.org/10.1016/j.margeo.2006.11.001

Martins, V., Jouanneau, J.-M., Weber, O., Rocha, F., 2006. Tracing the late Holocene evolution of the NW Iberian upwelling system. Marine Micropaleontology 59, 35-55. doi:10.1016/j.marmicro.2005.12.002

Martins, V., Gomes, V., 2004. Foraminíferos da Margem Continental NW Ibérica: Sistemática, Ecologia. Gomes, C. (Ed.), 377 pp (in Portuguese). ISSN 0207-775-04

Mateu, G., 1970. Estudio sistemático y bioecológico de los foraminíferos vivientes de los litorales de Cataluña y Baleares. Trabajos del Instituto Español de Oceanografía 38, 85 pp.

Mathieu, R., 1986. Sediments et Foraminiferes actuels et ressurgences cotieres sur la marge continentale Atlantique du Maroc: living foraminifera and upwelling on the Atlantic Continental Margin of Morocco. Revue de Paléobiologie, 
Benthos' 86, International Symposium Benthic Foraminifera, Vol. Spéc. n. ${ }^{\circ}$ 2, Genève, pp. 845-850.

Mendes I, Gonzalez R, Dias J, Lobo, F, Martins V., 2004. Factors Influencing Recent Benthic Foraminifera Distribution on the Guadiana Shelf (Southwestern Iberia). Marine Micropaleontology 51, 171-192.

Merkado G, Titelboim D, Hyams-Kaphza O, Holzmann M, Pawlowski J, Almogi-Labin, A., Abdu, U., Herut, B., Abramovich, S., 2015. Molecular phylogeny and ecology of d'Orbigny from the Mediterranean coast of Israel: a case of a successful new incumbent. PLoS ONE 10(11):e0142263. doi:10.1371/journal.pone.0142263

Mikhalevich, V.I., 1992. Makrosistema foraminifer [The macrosystem of the Foraminifera] Doct. Thes. St.-Pb., 1-43 (in Russian).

Mikhalevich, V.I., 1980. Sistematika i evolyuciya foraminifer v svete novyikh dannyikh po ih citologiii ul'trastrukture [Systematics and evolution of the Foraminifera in view of the new data on their cytology and ultrastructure]. In: Printsipy postroeniya makrosistemy odnokletochnykh zhivotnykh. Trudy Zoologicheskogo instituta Akademii Nauk SSSR [Principles of forming the macrosystem of unicellular animals]. Krylova MV, Starobogatova YaI, editors. 94, 42-61 (in Russian).

Murray, J., 2006. Ecology and Applications of Benthic Foraminifera. Ecology and Applications of Benthic Foraminifera Cambridge University Press.

Murray, J.W., 1991. Ecology and Palaeoecology of Benthic Foraminifera. London, Longman Scientific and Technical, 397 pp.

Murray, J.W., 1970. Living foraminifers of the Western Approaches to the English Channel. Micropaleontology 16 (4), 471-485.

Nørvang, A., 1966. Textularia nov. gen., Textularia Defrance and Spiroplectammina Cushman (Foraminifera). Biologiske Skrifter 15(3), 1-16.

Pawlowski, J., Holzmann, M., Tyszka, J., 2013. New supraordinal classification of Foraminifera: Molecules meet morphology. Marine Micropaleontology 100, 1-10. doi: 10.1016/j.marmicro.2013.04.002

Pujos, M., 1976. Ecologie des foraminiferes benthiques et des thecamoebiens de la Girond et du plateu continental sudGascogne. Application a la connaissance du Quaternaire terminal de la region ouest-Gironde. Thèse Doctorat d' Ètat ès Sciences, Univ. Bordeaux I, Mémoires de l'Institute de Geologie du Bassin d'Aquitaine, Bordeaux, vol. 8, 274 pp.

Reuss, A.E., 1850. Neue Foraminiferen aus den Schichten des Österreichischen Tertiärbeckens. Akademie der Wissenschaften,
Vienna. Mathematisch-naturwissenschaftliche Klasse. Denkschriften, Bd. 1, 1. Abth.

Robertson, B.R., 1998. Systematics and paleoecology of the benthic foraminiferida from the Buff Bay section, Miocene of Jamica. Micropaleontology, 44, supplement 2, 266 pp.

Saidova, Kh. M., 1981. O sovremennom sostoyanii sistemy nadvidovykh taksonov kaynozoyskikh bentosnykh foraminifer [The present state of supra-species taxa of Cenozoic benthic foraminifera]. Moscow: Institut okeanologii im. Shirshova Akademii Nayk SSSR Publ. 73 p (in Russian).

Sánchez-Arisa, M. del C., 1983. Specific associations of recent benthic foraminifera of the Neritic zone in the Montril-Nerja area, Spain, as a function of depth: diversity and constancy. Journal of Foraminiferal Research 13 (1), 13-20.

Schwager, C., 1877. Quadro del proposto sistema di clasificazionedei foraminiferi con guscio, Bolletino R. Comitato Geologico d' Italia 8, 18-27.

Sen Gupta, B.K. (ed.), 1999. Modern Foraminifera. Kluwer Academic Publishers, Dordrecht/Boston/London, pp. 371.

Semensatto-Jr, D.L., Dias-Brito, D., 2004. Análise ambiental de uma área parálica no delta do Rio São Francisco, Sergipe-Brasil, com base na sinecologia de foraminíferos e tecamebas (protista). Revista Brasileira de Paleontologia 7(1), 53-66.

Simkiss, K., 1977. Biomineralization and detoxification. Calcified Tissue Research, 24, 199-200.

Solomon, A.K., 1962. Pumps in the living cell. Scientific American. 207 (2): 100-8. doi:10.1038/scientificamerican0862-100. PMID13914986.

Sprovieri, R., Hasegawa, S., 1990. Plio-Pleistocene benthic foraminifer stratigraphic distribution in the deep-sea record of the Tyrrhenian Sea (ODP Leg 107). In Kastens, K. A., Masle, J. et al. (Eds.), Proceedings of the Ocean Drilling Program, Scientific Results 107, 429-459.

Stigter, H.C., Jorissen, E.J., Zwaan, V.D., 1998. Bathymetric distribution and microhabitat partionating of live (Rose Bengal Stained) benthic foraminifera along a shelf to bathial transect in the southern Adriatic Sea. Journal of Foraminiferal Research 28 (1), 40-65.

Yassini, I., Jones, B.G, 1995. Foraminiferida and ostracoda from estuarine and shelf environments on the southeastern coast of Australia. Wollong, N. S. W. The University os Wollongong Press, Australia, 484 pp.

Zheng, S.Y., 1988. The agglutinated and porcelaneous foraminifera of the East China Sea. China Ocean Press, Beijing, 337 p (in Chinese). 